\title{
Stereoselective Synthesis of all Possible Phosferrox Ligand Diastereoi- somers Displaying Three Elements of Chirality: Stereochemical Optimi- zation for Asymmetric Catalysis
}

\author{
Ross A. Arthurs, David L. Hughes and Christopher J. Richards* \\ School of Chemistry, University of East Anglia, Norwich Research Park, Norwich, NR4 7TJ, U.K. \\ Supporting Information Placeholder
}

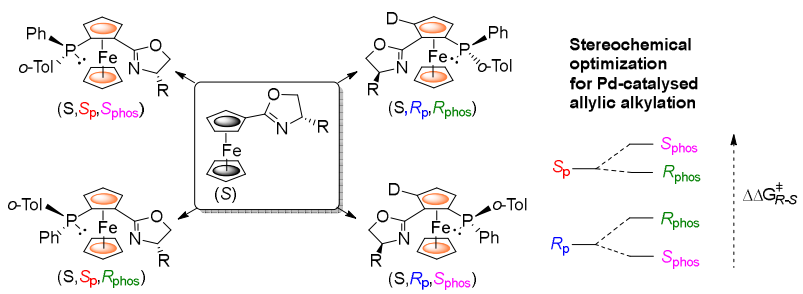

\begin{abstract}
All four possible diastereoisomers of phosphinoferrocenyloxazoline (Phosferrox type) ligands containing three elements of chirality were synthesized as single enantiomers. The $S_{\mathrm{c}}$ configured oxazoline moiety $(\mathrm{R}=\mathrm{Me}, i$-Pr) was used to control the generation of planar chirality by lithiation, with the alternative diastereoisomer formed by use of a deuterium blocking group. In each case subsequent addition of $\mathrm{PhPCl}_{2}$ followed by $o$-TolMgBr resulted in a single $P$-stereogenic diastereoisomer $\left(S_{\mathrm{c}}, S_{\mathrm{p}}, S_{\mathrm{phos}}\right.$ and $S_{\mathrm{c}}, R_{\mathrm{p}}, R_{\mathrm{phos}}$ respectively). The alternative diastereoisomers were formed selectively by addition of $o$ $\mathrm{TolPCl}_{2}$ followed by $\mathrm{PhMgBr}\left(\left(S_{\mathrm{c}}, S_{\mathrm{p}}, R_{\mathrm{phos}}\right.\right.$ and $S_{\mathrm{c}}, R_{\mathrm{p}}, S_{\mathrm{phos}}$ respectively). Preliminary application of these four ligand diastereoisomers, together with $\left(S_{\mathrm{c}}, S_{\mathrm{p}}\right)$ and $\left(S_{\mathrm{c}}, R_{\mathrm{p}}\right)$ Phosferrox $\left(\mathrm{PPh}_{2}\right)$, to palladium catalysed allylic alkylation of trans-1,3-diphenylallyl acetate revealed a stepwise increase/decrease in ee, with the configuration of the matched/matched diastereoisomer as $S_{\mathrm{c},} S_{\mathrm{p},} S_{\mathrm{phos}}(97 \%$ ee).
\end{abstract}

\section{INTRODUCTION}

Metal-based asymmetric catalysis is a major branch of organic chemistry that is exploited widely for the synthesis of research-focused and economically important compounds. ${ }^{1}$ To these ends the discovery of a new metal-catalysed reaction is frequently followed by work aimed at extending the reaction to the formation of enantioenriched chiral products. This process typically requires the screening of many chiral non-racemic ligands to achieve the goal of high enantioselectivity. ${ }^{2}$ The choice of ligands screened may be guided by the success of related chemistry, and/or ligand availability, many of which may be sourced commercially. Certain ligand types have proven to be successful in a number of different reactions, and as a result these have been described as 'privileged'. ${ }^{3}$ Once identified as such many analogous ligands, based on the same core structure, are frequently synthesized by substituent variation. In this way multiple ligands closely related to, for example, BINAP, ${ }^{4} \mathrm{Jo}-$ siphos $^{5}$ and Walphos ${ }^{6}$ are known, and many are commercially available (Figure 1).

Although specific advantages have been identified for the use of $C_{2}$-symmetric ligands in asymmetric catalysis $(e . g$. BINAP), ${ }^{7} C_{1}$-symmetric ligands have also found widespread use. These frequently contain two elements of chirality (e.g. Josiphos and Walphos) such that two diastereoisomers are potentially available. Typically only one of the two is usually explored, this being primarily a consequence of synthetic availablity. ${ }^{8}$ In cases where both diastereomeric ligands are tested in a metal-catalysed reaction, the matched and mismatched chirality pairings are usually identified readily. ${ }^{9}$<smiles>[R]c1cc2ccccc2c(-c2c([R2])c([R])cc3ccccc23)c1[R2]</smiles>

$\left(S_{a}\right)$

BINAP type

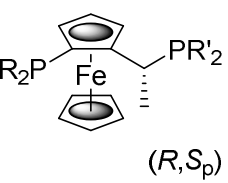

$\left(R, S_{p}\right)$

Josiphos type<smiles>[R20]c1ccccc1-c1ccccc1C(C)P</smiles>

$\left(R, R_{\mathrm{p}}\right)$
Figure 1. Representative 'privileged' and commercially available ligands for which multiple variation of the substituents (R/R') has been demonstrated.

This basis of ligand selection may potentially be expanded to the use of all four possible diastereoisomers arising from a ligand containing three elements of chirality. The 
configuration of each of the these will likely have a significant influence on product enantioselectivity, and the optimum relative configuration may well be reaction dependent. This has the potential to provide an alternative pathway to ligand optimization in asymmetric catalysis. To the best of our knowledge such methodology has not been described previously. ${ }^{10}$

\section{RESULTS AND DISCUSSION}

Our approach to achieving the selective synthesis of all four possible enantiopure diastereoisomers of a chiral bidentate ligand started with ferrocenyloxazoline $(S)-\mathbf{1 a}(\mathrm{R}=i$-Pr). This is known to undergo highly diastereoselective lithiation $(\mathrm{dr}>100: 1),{ }^{11}$ such that subsequent addition of $\mathrm{Ph}_{2} \mathrm{PCl}$ results in bidentate ligand $\left(S, S_{\mathrm{p}}\right)-\mathbf{L 1 a}$ (Scheme 1$) .{ }^{12}$ This ligand has been applied extensively in metal-catalysed asymmetric synthesis (Pd, Ru, Ir, Cu, Ag, Ni). ${ }^{13}$ We recently reported the adaptation of this lithiation/ $\mathrm{Ph}_{2} \mathrm{PCl}$ quench procedure for the selective synthesis of the corresponding diastereomeric ligand. Specifically, initial selective lithiation is followed by introduction of deuterium to give $\left(S, R_{\mathrm{p}}\right)-2-d$ $\mathbf{1 a},{ }^{14}$ such that a second lithiation, under non-selective conditions, is instead controlled by the introduced isotope $\left(k_{\mathrm{H}} / k_{\mathrm{D}} \sim 20\right)$. Following addition of $\mathrm{Ph}_{2} \mathrm{PCl}$ the target product $\left(S, R_{\mathrm{p}}-5-d-\mathbf{L} \mathbf{2 a}\right)$ is obtained predominantly as one diastereoisomer $(\mathrm{dr}=10: 1$ - Scheme 1$) .{ }^{15}$ Corresponding ligands $\left(S, S_{\mathrm{p}}\right)$-L1b and $\left(S, R_{\mathrm{p}}-5-d-\mathbf{L} \mathbf{2 b}\right)$ have been obtained in the same way from ferrocenyloxazoline $(S)-\mathbf{1 b}(\mathrm{R}=$ Me). ${ }^{12 c, 15}$

Scheme 1. Oxazoline auxiliary mediated control of planar chiral diastereoselectivity $\left(S, S_{\mathrm{p}}\right)$, and adaption by use of a deuterium blocking group $\left(S, R_{\mathrm{p}}\right)$.

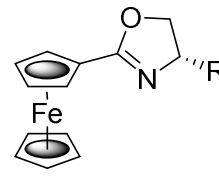

(S)-1a $(\mathrm{R}=i-\mathrm{Pr})$ (S) $-1 \mathbf{b}(\mathrm{R}=\mathrm{Me})$

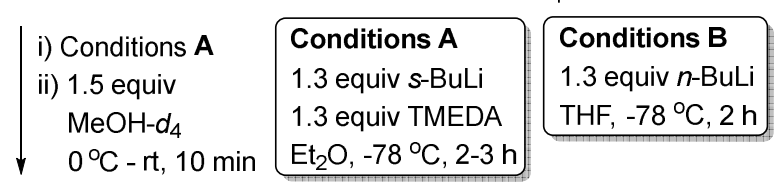

$\left(S, R_{\mathrm{p}}\right)-2-d-1 \mathbf{a} / \mathbf{b}$

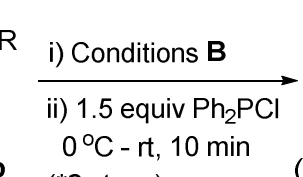

( ${ }^{*} 2$ steps)

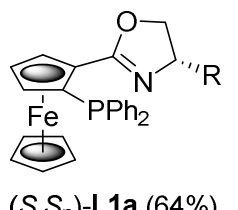

$\left(S, S_{\mathrm{p}}\right)-$ L1a $(64 \%)$ $\left(S, S_{\mathrm{p}}\right)$-L1b $(59 \%)$

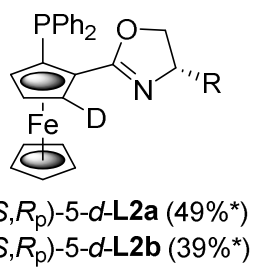

In order to extend this chemistry for the introduction of a third element of chirality we considered procedures for the selective creation of a phosphorus-based stereogenic center. Although many methods are known for the stereocontrolled synthesis of $P$-stereogenic compounds, ${ }^{16}$ in this instance efficiency would result if the lithiated planar chiral precursor to phosphorus introduction could be used to control diastereoselectivity. There are several reports in the literature of the reaction of chiral nucleophiles with $\mathrm{RPX}_{2}(\mathrm{X}=$
$\mathrm{Cl}, \mathrm{NEt}_{2}$ ) where differential replacement of both leaving groups X leads to a product in high diastereoselectivity. ${ }^{17} \mathrm{~A}$ further example is the use of lithiated planar chiral Ugi's amine as the nucleophile for the first step, followed by addition of an aryl Grignard reagent, to give $P$-stereogenic P-N ligands in high $\mathrm{dr}^{18}$

Accordingly, diastereoselective lithiation at $-78^{\circ} \mathrm{C}$ of $(S)$ 1a (conditions A) was followed by addition of $\mathrm{PPhCl}_{2}$ and warming of the reaction mixture to room temperature. After re-cooling to $-78^{\circ} \mathrm{C}$, subsequent addition of $o$-TolMgBr, followed by warming of the reaction mixture to room temperature and work-up, resulted in the isolation of a new Phosferrox ligand. After purification by column chromatography and recrystallisation, the product was identified as $\left(S, S_{\mathrm{p}}, S_{\text {phos }}\right)$-L3a following determination of the X-ray crystal structure (Scheme 2, Figure 2). ${ }^{19}$ Use of the same methodology, but instead with $o$-TolPCl 2 and $\mathrm{PhMgBr}$ as reagents, resulted in the formation of the alternative $P$-stereogenic diastereoisomer $\left(S, S_{\mathrm{p}}, R_{\mathrm{phos}}\right)$-L4a, an outcome again confirmed by determination of the X-ray crystal structure (Figure 3). ${ }^{19}$ In both cases the new phosphorus-based stereogenic center is formed with high diastereoselectivity (vide infra). As lithiation of $(S)-\mathbf{1 b}$ is also known to proceed with high diastereselectivity,12c,15 this enabled the application of this methodology to the synthesis of $\left(S, S_{\mathrm{p}}, S_{\mathrm{phos}}\right)-\mathbf{L} \mathbf{3} \mathbf{b}$ and $\left(S, S_{\mathrm{p}}, R_{\mathrm{phos}}\right)$ $\mathbf{L 4 b}$, both isolated as single diastereoisomers following column chromatography.

Scheme 2. Stereoselective synthesis of $P$-stereogenic diastereoisomers $\left(S, S_{\mathrm{p}}, S_{\mathrm{phos}}\right)-\mathbf{L} \mathbf{3 a} / \mathbf{b}$ and $\left(S, S_{\mathrm{p}}, R_{\mathrm{phos}}\right)-\mathbf{L 4 a} / \mathbf{b}$.

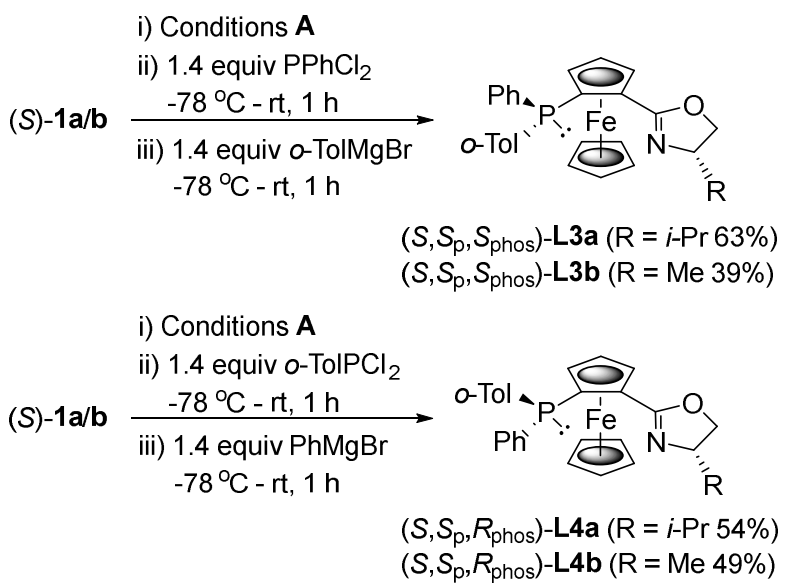

The extension of this methodology to the synthesis of the remaining two planar chiral diastereoisomers started with $\left(S, R_{\mathrm{p}}\right)-2-d-1 \mathrm{a}$ (>90\% D incorporation). ${ }^{15}$ Use of lithiation conditions $\mathrm{B}$, followed by addition of $o-\mathrm{TolPCl}_{2}$ and then $\mathrm{PhMgBr}$ as before, led to isolation of a single Phosferrox derivative containing $n$-butyl and ortho-tolyl groups $(14 \%$ yield). The competitive and undesired reaction of $n$-BuLi led us to evaluate $s$-BuLi/THF as an alternative base/solvent combination for this reaction. These conditions (C) applied previously to the lithiation of $(S)$-1a resulted in an $8: 1 \mathrm{dr}, 11$ therefore allowing the larger kinetic isotope effect associated with lithiation ${ }^{20}$ to dominate planar chiral diastereoselectivity. To confirm this, application of conditions $C$ to the lithiation of $\left(S, R_{\mathrm{p}}\right)-2-\mathrm{d}-1 \mathrm{a}$ followed by addition of TMSCl 
resulted in a $5: 1$ ratio of the resulting silylated $\left(S, R_{\mathrm{p}}\right):(S$, $S_{\mathrm{p}}$ ) diastereoisomers (68\% yield). Furthermore, lithiation in the same way, followed by addition of $o$-TolPCl 2 and then $\mathrm{BuMgCl}$, led to the predominant formation of the same Phosferrox derivative formed when using $n$-BuLi as base, assigned as $\left(S, R_{\mathrm{p}}, S_{\mathrm{phos}}\right)$-2a by analogy to the chemistry described above (Scheme 3).

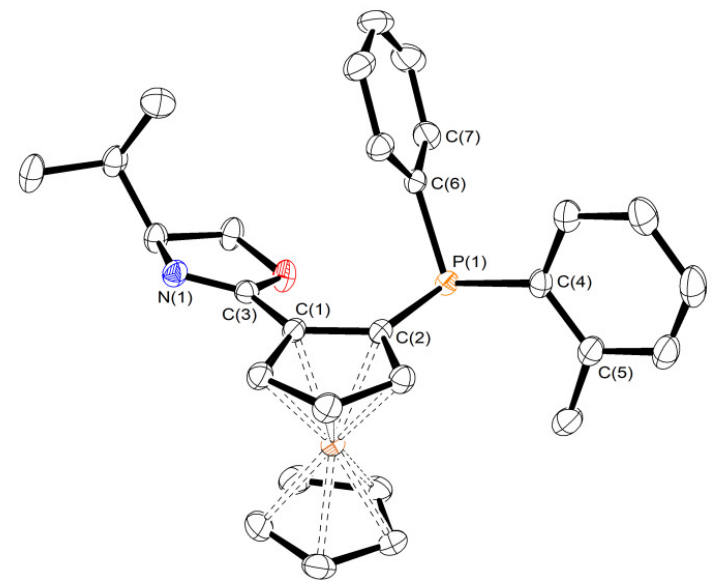

Figure 2. Representation of the X-ray crystal structure of $\left(S, S_{\mathrm{p}}, S_{\text {phos }}\right)$-L3a (hydrogen atoms omitted for clarity). Principal bond lengths $[\AA]$ include: C(1)-C(3) 1.460(2), C(2)-P(1) 1.8283(18). Principal torsions $\left[{ }^{\circ}\right]$ include: $\mathrm{C}(2)-\mathrm{C}(1)-\mathrm{C}(3)-\mathrm{N}(1)$ -159.38(19), C(1)-C(2)-P(1)-C(6) 58.74(17), C(1)-C(2)-P(1)$\mathrm{C}(4)$ 162.54(16), C(2)-P(1)-C(6)-C(7) -154.48(15), C(2)-P(1)$\mathrm{C}(4)-\mathrm{C}(5) 86.89(15)$. Thermal ellipsoids are drawn at the $50 \%$ probability level.

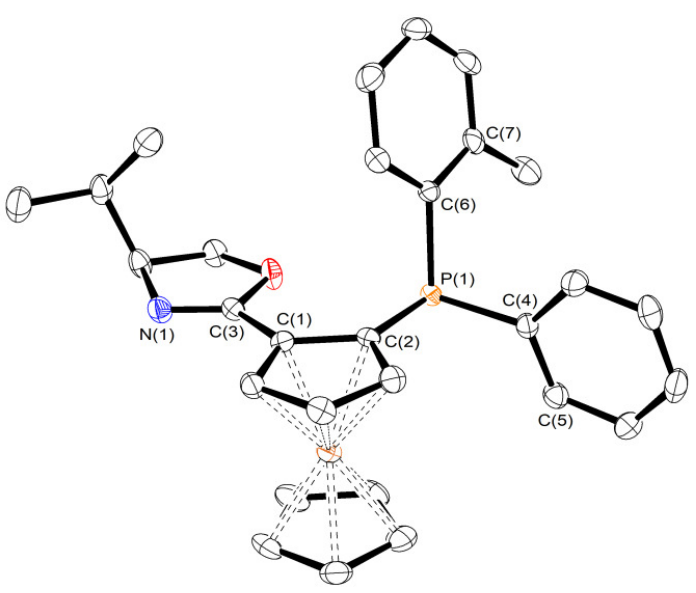

Figure 3. Representation of the X-ray crystal structure of $\left(S, S_{\mathrm{p}}, R_{\text {phos }}\right)$-L4a (hydrogen atoms omitted for clarity). Principal bond lengths $[\AA]$ include: $\mathrm{C}(1)-\mathrm{C}(3)$ 1.458(4), C(2)-P(1) 1.826(3). Principal torsions $\left[{ }^{\circ}\right]$ include: $\mathrm{C}(2)-\mathrm{C}(1)-\mathrm{C}(3)-\mathrm{N}(1)-$ 175.6(3), C(1)-C(2)-P(1)-C(6) 83.7(3), C(1)-C(2)-P(1)-C(4) 172.2(3), C(2)-P(1)-C(6)-C(7) 176.3(2), C(2)-P(1)-C(4)-C(5) $92.6(3)$. Thermal ellipsoids are drawn at the $50 \%$ probability level.
Scheme 3. Demonstration of deuterium mediated planar chirality reversal with configurational control of a phosphorus based stereogenic center.

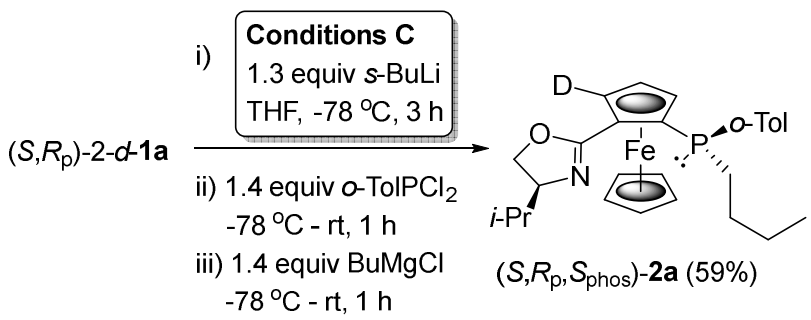

Scheme 4. Stereoselective synthesis of $P$-stereogenic diastereoisomers $\left(S, R_{\mathrm{p}}, R_{\text {phos }}\right)-\mathbf{L} \mathbf{5}$ and $\left(S, R_{\mathrm{p}}, S_{\text {phos }}\right)-\mathbf{L} 6,{ }^{\ddagger}(\mathrm{dr}=15$ : 1 for $\mathbf{L} \mathbf{5 b}$ ).

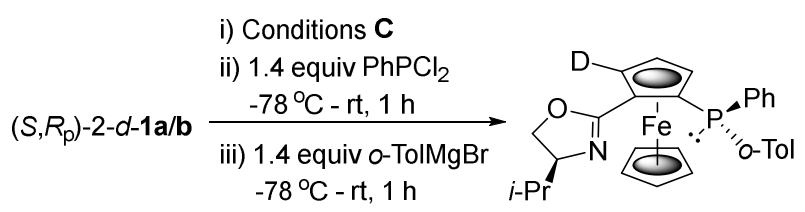

$\left(S, R_{\mathrm{p}}, R_{\mathrm{phos}}\right)-5-d-$ L5a $(\mathrm{R}=i-\operatorname{Pr} 59 \%)$

$\left(S, R_{p}, R_{\text {phos }}\right)-5-d-$ L5b $(R=\operatorname{Me~} 17 \%)^{\ddagger}$

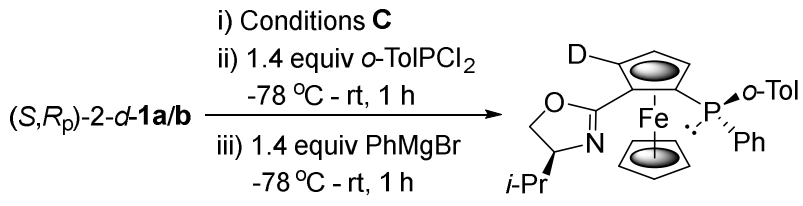

( $\left.S, R_{\mathrm{p}}, S_{\mathrm{phos}}\right)-5-d-\mathrm{L} 6 \mathrm{a}(\mathrm{R}=i-\operatorname{Pr} 58 \%)$ $\left(S, R_{\mathrm{p}}, S_{\text {phos }}\right)-5-d-$ L6b $(\mathrm{R}=\mathrm{Me} 29 \%)$

Conditions $\mathrm{C}$ were then used for the synthesis of $\left(S, R_{\mathrm{p}}, R_{\mathrm{phos}}\right)-5$ - $d$-L5a and $\left(S, R_{\mathrm{p}}, S_{\mathrm{phos}}\right)-5$ - $d$-L6a (Scheme 4$)$. For both reactions comparison of the ${ }^{31} \mathrm{P}$ NMR spectra obtained after work-up again revealed excellent configurational control of the phosphorus-based stereogenic center. Separation of the product from the alternative planar chiral diastereoisomer was achieved readily by column chromatography. This chemistry was extended to the synthesis of $\left(S, R_{\mathrm{p}}, R_{\mathrm{phos}}\right)-$ 5- $d$-L5b and $\left(S, R_{\mathrm{p}}, S_{\text {phos }}\right)-5-d-\mathbf{L} \mathbf{6 b}$, both isolated predominantly as a single diastereoisomer following column chromatography, and in the case of $\left(S, R_{\mathrm{p}}, S_{\mathrm{phos}}\right)-\mathbf{L} \mathbf{6 b}$ as a single isomer by a subsequent recrystallisation. The configuration of $\left(S, R_{\mathrm{p}}, S_{\mathrm{phos}}\right)$ - $\mathbf{L} \mathbf{6 b}$ was established by an X-ray crystal structure determination (Figure 4), ${ }^{19}$ confirming that it is the planar chirality, and not the oxazoline-based stereogenic center, that exclusively controls the configuration of the phosphorus based stereogenic center. 


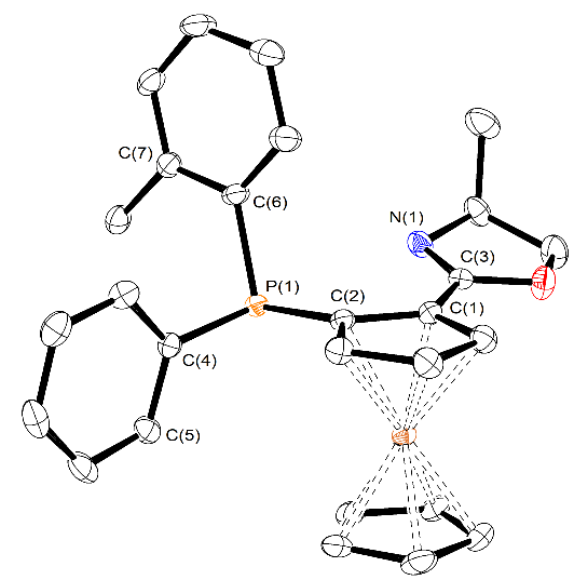

Figure 4. Representation of the X-ray crystal structure of $\left(S, R_{\mathrm{p}}, S_{\mathrm{phos}}\right)$-L6b (hydrogen and deuterium atoms omitted for clarity). Principal bond lengths $[\AA]$ include: $C(1)-C(3) 1.460(5)$, $\mathrm{C}(2)-\mathrm{P}(1)$ 1.828(4). Principal torsions $\left[{ }^{\circ}\right]$ include: $\mathrm{C}(2)-\mathrm{C}(1)-$ C(3)-N(1) 7.5(7), C(1)-C(2)-P(1)-C(6) -89.2(4), C(1)-C(2)-P(1)C(4) 169.7(3), C(2)-P(1)-C(6)-C(7) -173.0(3), C(2)-P(1)-C(4)C(5) -93.3(3). Thermal ellipsoids are drawn at the $50 \%$ probability level.

All four $P$-stereogenic diastereoisomers (L3a/b-L6a/b) were obtained by column chromatography on silica. In some instances epimerization was noted, as has been observed previously for other $P$-stereogenic compounds containing a ferrocenyl substituent. ${ }^{18 a, 21,22}$ To investigate this further, a $1: 0.2$ ratio of $\left(S, S_{\mathrm{p}}, S_{\mathrm{phos}}\right)-\mathbf{L} \mathbf{3 a} /\left(S, S_{\mathrm{p}}, R_{\mathrm{phos}}\right)-\mathbf{L} \mathbf{4 a}$ was heated for $24 \mathrm{~h}$ at $65^{\circ} \mathrm{C}$ in hexane containing chromatography grade $\mathrm{SiO}_{2}(40-65 \mu \mathrm{m})$. This resulted in a change in ratio to $1: 1$, whereas the in the absence of $\mathrm{SiO}_{2}$, or with added neutral $\mathrm{Al}_{2} \mathrm{O}_{3}(10-200 \mu \mathrm{m})$, no change was observed. Similarly, heating initially pure $\left(S, R_{\mathrm{p}}, R_{\text {phos }}\right)-5$-d-L5a in silica doped hexane for $24 \mathrm{~h}$ at $65{ }^{\circ} \mathrm{C}$ gave a $1: 0.5$ ratio of $\left(S, R_{\mathrm{p}}, R_{\text {phos }}\right)-5$ - $d$-L5a $/\left(S, R_{\mathrm{p}}, S_{\text {phos }}\right)-5$ - $d$-L6a. The promotion of epimerization by $\mathrm{SiO}_{2}$ is likely related to its acidity. ${ }^{23,24}$

The excellent diastereoselectivity observed for the formation of the $P$-stereogenic ligands could be a consequence of highly selective differentiation, on substitution, of the two enantiotopic chlorine components of $\mathrm{ArPCl}_{2}$ to give 3 (kinetic control). Alternatively, this first step in the reaction could proceed without selectivity, requiring a subsequent epimerization step to produce a single isomer (thermodynamic control). To investigate this further the synthesis of $\left(S, S_{\mathrm{p}}, R_{\text {phos }}\right)$-L4a was repeated, with examination by ${ }^{31} \mathrm{P}$ NMR spectroscopy of the reaction mixture after addition $o$ $\mathrm{TolPCl}_{2}$ and warming to room temperature (Scheme 5). This revealed a major signal at $67.7 \mathrm{ppm}$, and following addition of $\mathrm{PhMgBr}$ this signal disappeared and was replaced by the ${ }^{31} \mathrm{P}$ NMR signal for $\left(S, S_{\mathrm{p}}, R_{\mathrm{phos}}\right)$-L4a $(-23.9 \mathrm{ppm})$. No signal was observed for $\left(S, S_{\mathrm{p}}, S_{\text {phos }}\right)$-L3a ( $\left.c a .-28 \mathrm{ppm}\right)$, from which the diastereoselectivity is estimated as $>100: 1$.
Scheme 5. Planar chiral stereocontrol in the synthesis of $P$ stereogenic diastereoisomer $\left(S, S_{\mathrm{p}}, R_{\text {phos }}\right)-\mathbf{L 4 a}$.

$$
\begin{aligned}
& \text { epimerisation } \\
& \left(S, S_{\mathrm{p}}\right)-\mathbf{3} \\
& \text { ii) Conditions } \mathbf{A} \\
& \text { ii) o-TolPCl } 2 \text { (non-selective) } \\
& \left(S, S_{p}, S_{\text {phos }}\right)-4 \\
& \text { S)-1a } \\
& \text { iii) } \mathrm{PhMgBr} \\
& \mathrm{S}_{\mathrm{N}} 2 \text { (inversion) }
\end{aligned}
$$

Attempts to isolate and further characterize the intermediate were unsuccessful. There are three pointers to the intermediate being $\left(S, S_{\mathrm{p}}, S_{\mathrm{phos}}\right)-\mathbf{4},{ }^{18}$ although these do not rule out other possibilities. Firstly, aryl/lone-pair differentiation, with the aryl group oriented away from ferrocene in this cyclic structure, provides a basis for epimerization selectivity. Thermodynamic control of this sort has been used to explain the diastereoselective formation of other auxiliary mediated $P$-stereogenic derivatives. ${ }^{17,25}$ Secondly, stereospecific $\mathrm{S}_{\mathrm{N}} 2$ reaction with $\mathrm{PhMgBr}$ accounts for the configuration of the phosphorus-based stereogenic center in $\left(S, S_{\mathrm{p}}, R_{\text {phos }}\right)$-L4a. Finally, the observed ${ }^{31} \mathrm{P}$ NMR chemical shift of $67.7 \mathrm{ppm}$ is in reasonable agreement with the value estimated for this intermediate (ca. $72 \mathrm{ppm})$. This was determined starting with the reported value of $88 \mathrm{ppm}^{26}$ for (DMAP) $\mathrm{Ph}_{2} \mathrm{P}^{+} \mathrm{TfO}^{-}$corrected for the replacement of both phenyls by a ferrocenyl (-9.4 ppm) and an ortho-tolyl (-6.4 ppm) group. ${ }^{27}$

Table 1. Palladium catalysed allylic alkylation with ligands L1a-L6a.

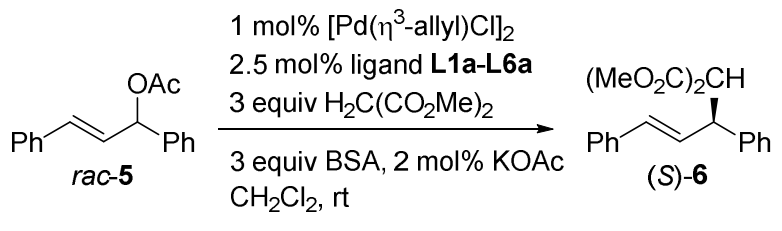

\begin{tabular}{ccccc}
\hline Entry & Ligand & $\begin{array}{c}\text { Time } \\
(\mathrm{h})\end{array}$ & $\begin{array}{c}\text { Conversion } \\
(\%)^{[\mathrm{a}]}\end{array}$ & ee\%[b] \\
\hline 1 & $\left(S, S_{\mathrm{p}}\right)-\mathbf{L 1 a}$ & $<1$ & 100 & 95 \\
2 & $\left(S, R_{\mathrm{p}}\right)-5-\mathrm{d}-\mathbf{L} \mathbf{2 a}$ & 24 & 92 & 71 \\
3 & $\left(S, S_{\mathrm{p}}, S_{\text {phos }}\right)-\mathbf{L 3 a}$ & 5 & 100 & 97 \\
4 & $\left(S, S_{\mathrm{p}}, R_{\text {phos }}\right)-\mathbf{L 4 a}$ & 7 & 100 & 95 \\
5 & $\left(S, R_{\mathrm{p}}, R_{\text {phos }}\right)-5-\mathrm{d}-$ & 24 & 90 & 84 \\
& L5a & & & 63 \\
6 & $\left(S, R_{\mathrm{p}}, S_{\text {phos }}\right)-5-\mathrm{d}-$ & 24 & 86 & 63 \\
& L6a & & & \\
\hline
\end{tabular}

[a] Determined by ${ }^{1} \mathrm{H}$ NMR spectroscopy. [b] Determined by chiral HPLC. (S)-6 was the major enantiomer in all cases.

The availability of all four ligand diastereoisomers enabled a preliminary investigation into the influence of ligand configuration on enantioselectivity. To this end we chose as a model reaction palladium catalysed allylic alkylation of rac-5 as $t$-Bu substituted Phosferrox ligands are known to work well in this chemistry. ${ }^{13 a, 28}$ In addition to $i$-Pr 
substituted diastereomeric ligands L3a-L6a, precursor ligands L1a and L2a were also employed. All ligands resulted in the formation of $(S)-\mathbf{6}$ as the major enantiomer, and the ee values obtained (Table 1 ) revealed a clear preference for the $S, S_{\mathrm{p}}$ diastereoisomers, with the $S, S_{\mathrm{p}}, S_{\mathrm{phos}}$ ligand L3a being the matched/matched diastereoisomer. A pictorial representation of these ee values highlights the additive/subtractive influence of the phosphorus-based stereogenic center (Figure 5a). Assuming the availability of only two diastereomeric transition states, ${ }^{29}$ an alternative representation of these results is as $\Delta \Delta \mathrm{G}^{\ddagger} R-S$ values (calculated with rt $=22{ }^{\circ} \mathrm{C}$ - Figure $5 \mathrm{~b}$ ). In both cases the phosphine based stereogenic center adds to $\Delta \Delta \mathrm{G}^{\ddagger} R-s$ a value of $\sim 2 \mathrm{~kJ} \mathrm{~mol}^{-1}$.

$$
\begin{aligned}
& \text { a) ee(\%) }
\end{aligned}
$$

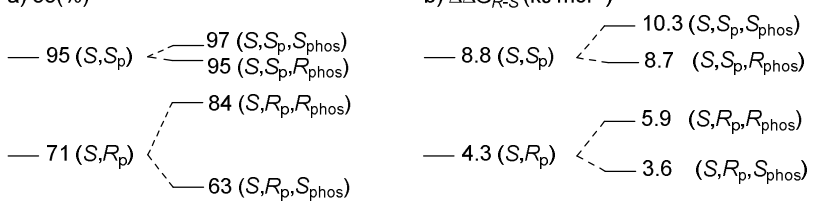

Figure 5. Outcomes of palladium catalysed allylic alkylation with ligands L1a-L6a.

\section{CONCLUSION}

We have demonstrated that sequential addition to a lithiated planar chiral ferrocenyloxazoline of $\mathrm{Ar}^{1} \mathrm{PCl}_{2}$ followed by $\mathrm{Ar}^{2} \mathrm{MgBr}$ results in a diarylferrocenyl phosphine with excellent control of diastereoselectivity. Coupled with the high diastereoselectivity of lithiation, as controlled by the $(S)$-valine or $(S)$-alanine derived oxazoline auxiliary, and the use of a deuterium blocking group to reverse lithiation diastereoselectivity, this enables the selective synthesis of all possible Phosferrox ligand diastereoisomers containing three elements of chirality. To the best of our knowledge this is the first time four diastereoisomers of a bidentate ligand have been synthesized. On application to palladium-catalysed allylic alkylation of trans-1,3-diphenylallyl acetate the configuration of the matched/matched $i$-Pr substituted ligand was identified as $S, S_{\mathrm{p}}, S_{\text {phos. }}$. Furthermore, comparison in catalysis to the simpler diphenylphosphine containing Phosferrox ligands reveals a positive and negative influence of the phosphorus-based stereogenic center. The results of this study concur with our previous literature analysis on the addition of an element of chirality to a parent ferrocenebased ligand to give both possible diastereomeric offspring ligands. ${ }^{30}$ In nearly all cases this analysis revealed (in 20 out of 23 examples), as in this work, a systematic increase and decrease in ee, providing further support for the iterative use of this approach in ligand optimization studies. Application of the new ligands in this way is currently in progress.

\section{EXPERIMENTAL SECTION}

General remarks. Diethyl ether and tetrahydrofuran were distilled over sodium and benzophenone ketyl. Tetramethylethylenediamine (TMEDA) was dried with $4 \AA$ MS. All lithiation reactions were carried out under an inert atmosphere of either nitrogen or argon. Alkyllithiums and Grignards were not titrated prior to use. Silica gel (60 Å pore size, 40 - $63 \mu \mathrm{m}$ technical grade) was used for chromatography. All protons and carbons were assigned using 2D NMR techniques including HSQC, HMBC, NOESY and COESY.
Preparation of $\quad(S)-2-\left[\left(S_{\mathrm{p}}\right)-2-\left(\left(S_{\text {phos }}\right)\right.\right.$-ortho-tolylphenylphosphino)ferrocenyl]-4-(1-methylethyl)oxazoline, $\left(\boldsymbol{S}, \boldsymbol{S}_{\mathrm{p}}, \boldsymbol{S}_{\text {phos }}\right)$-L3a. $(S)$-1a $(0.100 \mathrm{~g}, 0.34 \mathrm{mmol})$ was added to a flame dried Schlenk tube under an inert atmosphere and dissolved in dry diethyl ether ( $4 \mathrm{~mL})$. TMEDA $(0.07 \mathrm{~mL}, 0.44 \mathrm{mmol})$ was added and solution was cooled to $-78{ }^{\circ} \mathrm{C}$ and stirred for $5 \mathrm{~min}$ after which $s$ butyllithium (1.4 M in hexanes) ( $0.31 \mathrm{~mL}, 0.44 \mathrm{mmol}$ ) was slowly added. After stirring for 3 hours, dichlorophenylphosphine ( $64 \mu \mathrm{l}$, $0.47 \mathrm{mmol}$ ) was added and the reaction allowed to stir at room temperature for $1 \mathrm{~h}$. The reaction was re-cooled to $-78{ }^{\circ} \mathrm{C}$ and $o$ tolylmagnesium bromide ( $2.0 \mathrm{M}$ in THF) $(0.24 \mathrm{~mL}, 0.47 \mathrm{mmol})$ was added and the reaction allowed to warm to room temperature and stir for an additional hour. The reaction was cooled to $0{ }^{\circ} \mathrm{C}$ quenched with saturated sodium carbonate solution and separated with diethyl ether, dried with magnesium sulphate and the solvent removed in vacuo. Purification by column chromatography $\left(\mathrm{SiO}_{2}\right.$, $10 \% \mathrm{EtOAc} /$ hexane) yielded an orange solid $(0.11 \mathrm{~g}, 63 \%) . R_{\mathrm{f}} 0.2$ (10\% EtOAc/hexane). Mp $150-151^{\circ} \mathrm{C} .[\alpha]_{\mathrm{D}}{ }^{25.5^{\circ} \mathrm{C}}=+120(c 0.20$, $\mathrm{CHCl}_{3}$ ). IR (film): 3053, 2955, 2926, 2873, 1656 (CN). ${ }^{1} \mathrm{H}$ NMR (500 $\left.\mathrm{MHz}, \mathrm{CDCl}_{3}\right)$ : $7.29-7.22(2 \mathrm{H}, \mathrm{m}, o-\mathrm{Tol} H), 7.23-7.15(5 \mathrm{H}, \mathrm{m}, \mathrm{Ph} H)$, 7.08 - $7.01(2 \mathrm{H}, \mathrm{m}, o-\mathrm{Tol} H), 5.09(1 \mathrm{H}, \mathrm{brs}, \mathrm{CpH}), 4.40(1 \mathrm{H}, \mathrm{brs}, \mathrm{CpH})$, $4.27\left(1 \mathrm{H}, \mathrm{apt},{ }^{2+3} \mathrm{~J}_{\mathrm{HH}}=8.9 \mathrm{~Hz}, \mathrm{CHH}\right), 4.22(5 \mathrm{H}, \mathrm{s}, \mathrm{CpH}), 3.85(1 \mathrm{H}, \mathrm{td}$, $\left.{ }^{2} J_{\mathrm{HH}}=9.0,{ }^{3} \mathrm{JHH}_{\mathrm{HH}}=6.2 \mathrm{~Hz}, \mathrm{CH}\right), 3.72(1 \mathrm{H}, \mathrm{s}, \mathrm{CpH}), 3.41\left(1 \mathrm{H}, \mathrm{apt},{ }^{2+3} \int_{\mathrm{HH}}\right.$ $=8.5 \mathrm{~Hz}, \mathrm{CHH}), 2.85\left(3 \mathrm{H}, \mathrm{s}, \mathrm{CH}_{3}\right), 1.62\left(1 \mathrm{H}\right.$, apoct, $3+3+3 \mathrm{H}_{\mathrm{HH}}=6.6 \mathrm{~Hz}$, $\mathrm{CH}), 0.83\left(3 \mathrm{H}, \mathrm{d},{ }^{3} \mathrm{JH}_{\mathrm{HH}}=6.8 \mathrm{~Hz}, \mathrm{CH}_{3}\right), 0.66\left(3 \mathrm{H}, \mathrm{d},{ }^{3} \mathrm{JH}_{\mathrm{HH}}=6.8 \mathrm{~Hz}, \mathrm{CH}_{3}\right)$. ${ }^{13} \mathrm{C}\left\{{ }^{1} \mathrm{H}\right\}$ NMR $\left(125 \mathrm{MHz}, \mathrm{CDCl}_{3}\right): 166.4(\mathrm{C}=\mathrm{N}), 143.5\left(\mathrm{~d},{ }^{2} J_{\mathrm{CP}}=27.4\right.$ $\mathrm{Hz}, o$-TolC), $140.5\left(\mathrm{~d},{ }^{1} J_{\mathrm{CP}}=13.0 \mathrm{~Hz}, \mathrm{Ph} C\right), 136.8\left(\mathrm{~d},{ }^{1} J_{\mathrm{CP}}=15.4 \mathrm{~Hz}, o-\right.$ $\mathrm{Tol} C$ ), $136.0\left(\mathrm{~d},{ }^{2} J_{\mathrm{CP}}=3.7 \mathrm{~Hz}, o-\mathrm{Tol} C\right), 132.4\left(\mathrm{~d},{ }^{2} \mathrm{CP}_{\mathrm{CP}}=20.4 \mathrm{~Hz}, \mathrm{Ph} C\right.$ ), $130.1\left(\mathrm{~d},{ }^{3} J_{\mathrm{CP}}=4.9 \mathrm{~Hz}, o-\mathrm{Tol} C\right), 129.2(o-\mathrm{Tol} C), 128.2\left(\mathrm{~d},{ }^{3} \mathrm{JP}_{\mathrm{CP}}=6.8\right.$ $\mathrm{Hz}, \mathrm{PhC}), 127.8(\mathrm{PhC}), 126.1\left(\mathrm{~d},{ }^{3} J_{\mathrm{CP}}=2.1 \mathrm{~Hz}, o-\mathrm{Tol} C\right), 79.8\left(\mathrm{~d},{ }^{2} J_{\mathrm{CP}}=\right.$ $17.6 \mathrm{~Hz}, \mathrm{CpC}$ ), $74.5(\mathrm{Cp} C), 74.2(\mathrm{Cp} C), 71.9(\mathrm{Cp} C), 71.6(\mathrm{CH}), 71.0$ $(2 \mathrm{CpC}), 70.1\left(\mathrm{CH}_{2}\right), 32.0(\mathrm{CH}), 22.2\left(\mathrm{~d},{ }^{3} \mathrm{CP}=22.9 \mathrm{~Hz}, \mathrm{CH}_{3}\right), 19.1$ $\left(\mathrm{CH}_{3}\right), 17.7\left(\mathrm{CH}_{3}\right) .{ }^{31} \mathrm{P}\left\{{ }^{1} \mathrm{H}\right\}$ NMR $\left(202 \mathrm{MHz}, \mathrm{CDCl}_{3}\right):-26.51$ (PPhoTol). HRMS (ASAP-TOF) $m / z:[\mathrm{M}+\mathrm{H}]^{+}$Calcd for $\mathrm{C}_{29} \mathrm{H}_{31} \mathrm{FeNOP}$ 496.1493; Found 496.1493

Preparation of dichloroortho-tolylphosphine. Bis(diethylamino)chlorophosphine $(5.00 \mathrm{~g}, 23.7 \mathrm{mmol})$ was added to a flame dried Schlenk tube, dissolved in diethyl ether $(25 \mathrm{~mL})$ and cooled to $-78^{\circ} \mathrm{C}$. Ortho-tolylmagnesium bromide (2M in THF) $(17.80 \mathrm{~mL}$ $35.6 \mathrm{mmol}$ ) was then added slowly and the reaction allowed to warm to room temperature and stirred vigorously for $1 \mathrm{~h}$. The resulting suspension was allowed to settle and the mother liquor transferred to a dry flask by cannula filtration, and the remaining white solid washed with diethyl ether $(3 \times 10 \mathrm{~mL})$. The solvent was then removed in vacuo and the resulting oil re-dissolved in fresh diethyl ether $(10 \mathrm{~mL})$. The flask was cooled to $0{ }^{\circ} \mathrm{C}$ and hydrogen

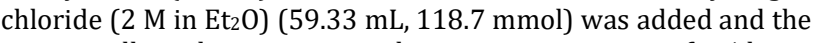
reaction allowed to stir vigorously at room temperature for 1 hour. Again, the resulting suspension was allowed to settle and the mother liquor transferred to a dry flask by cannula filtration, and the remaining white solid washed with diethyl ether $(3 \times 10 \mathrm{~mL})$. The solvent was removed in vacuo and the resulting oil purified by Kugelrohr distillation $\left(130-140{ }^{\circ} \mathrm{C} @ 7\right.$ mbar) to give a clear oil (2.53 g, $55 \%$ ): ${ }^{1} \mathrm{H}$ NMR $\left(500 \mathrm{MHz}, \mathrm{CDCl}_{3}\right): 8.05\left(1 \mathrm{H}, \mathrm{brd},{ }^{3}\right)_{\mathrm{HH}}=7.0$ $\mathrm{Hz}, \operatorname{Ar} H), 7.44\left(1 \mathrm{H}, \mathrm{apt},{ }^{3+3} J_{\mathrm{HH}}=7.4 \mathrm{~Hz}, \operatorname{Ar} H\right), 7.38\left(1 \mathrm{H}, \mathrm{apt},{ }^{3+3} J_{\mathrm{HH}}=\right.$ $7.3 \mathrm{~Hz}, \mathrm{Ar} H), 7.23\left(1 \mathrm{H}, \mathrm{brd},{ }^{3} J_{\mathrm{HH}}=7.2 \mathrm{~Hz}, \mathrm{Ar} H\right), 2.65\left(3 \mathrm{H}, \mathrm{s}, \mathrm{ArCH} \mathrm{H}_{3}\right)$. ${ }^{13} \mathrm{C}\left\{{ }^{1} \mathrm{H}\right\}$ NMR (125 MHz, CDCl 3$): 140.6\left(\mathrm{~d},{ }^{2} \mathrm{JCP}=35.5 \mathrm{~Hz}, \mathrm{ArC}\right), 137.9$ $\left(\mathrm{d},{ }^{1} J_{\mathrm{CP}}=57.5 \mathrm{~Hz}, \mathrm{ArC}\right), 132.7(\operatorname{ArC}), 130.9(\operatorname{ArC}), 130.4\left(\mathrm{~d},{ }^{2} J_{\mathrm{CP}}=11.1\right.$ $\mathrm{Hz}, \mathrm{ArC}), 127.1(\mathrm{ArC}), 20.0\left(\mathrm{~d},{ }^{3} \mathrm{JCP}=24.9 \mathrm{~Hz}, \mathrm{CH}_{3}\right) \cdot{ }^{31} \mathrm{P}\left\{{ }^{1} \mathrm{H}\right\} \mathrm{NMR}(202$ $\left.\mathrm{MHz}, \mathrm{CDCl}_{3}\right): 163.35\left(\mathrm{ClPAr}_{2}\right)$. Matches previously reported data. ${ }^{31}$ Preparation of $(S)-2-\left[\left(S_{\mathrm{p}}\right)-2-\left(\left(R_{\mathrm{phos}}\right)\right.\right.$-ortho-tolylphenylphosphino)ferrocenyl]-4-(1-methylethyl)oxazoline, $\left(\boldsymbol{S}, \boldsymbol{S}_{\mathrm{p}}, \boldsymbol{R}_{\text {phos }}\right)$-L4a. $(S)$-1a $(0.100 \mathrm{~g}, 0.34 \mathrm{mmol})$ was added to a flame dried Schlenk tube under an inert atmosphere and dissolved in dry diethyl ether ( $4 \mathrm{~mL}$ ). TMEDA (0.07 mL, $0.44 \mathrm{mmol}$ ) was added and solution was cooled to $-78{ }^{\circ} \mathrm{C}$ and stirred for $5 \mathrm{~min}$ after which $s$ butyllithium (1.4 M in hexanes) $(0.31 \mathrm{~mL}, 0.44 \mathrm{mmol}$ ) was slowly added. After stirring for 3 hours, ortho-tolyldichlorophosphine (64 $\mu \mathrm{l}, 0.47 \mathrm{mmol}$ ) was added and the reaction allowed to stir at room 
temperature for $1 \mathrm{~h}$. The reaction was re-cooled to $-78{ }^{\circ} \mathrm{C}$ and phenylmagnesium bromide (1.0 $\mathrm{M}$ in THF) $(0.47 \mathrm{~mL}, 0.47 \mathrm{mmol})$ was added and the reaction allowed to warm to room temperature and stir for an additional hour. The reaction was cooled to $0{ }^{\circ} \mathrm{C}$ quenched with saturated sodium carbonate solution and separated with diethyl ether, dried with magnesium sulphate and the solvent removed in vacuo. Purification by column chromatography $\left(\mathrm{SiO}_{2}\right.$, $10 \%$ EtOAc/hexane) yielded an orange solid $(0.09 \mathrm{~g}, 54 \%) . R_{\mathrm{f}} 0.3$ (10\% EtOAc/hexane). Mp $104-105{ }^{\circ} \mathrm{C} .[\alpha]_{\mathrm{D}} 25.5^{\circ} \mathrm{C}=+20(c 0.20$, $\mathrm{CHCl}_{3}$ ). IR (film): 3053, 2959, 2902, 2869, 1660 (CN). ${ }^{1} \mathrm{H}$ NMR (500 $\left.\mathrm{MHz}^{\mathrm{CDCl}} 3\right): 7.46\left(2 \mathrm{H}\right.$, aptd, $\left.{ }^{3} \mathrm{JHP}_{\mathrm{HP}}=7.3,{ }^{3} \mathrm{~J}_{\mathrm{HH}}=7.3,{ }^{4} J_{\mathrm{HH}}=2.2 \mathrm{~Hz}, \mathrm{PhH}\right)$, $7.38-7.34(3 \mathrm{H}, \mathrm{m}, \mathrm{PhH}), 7.14\left(1 \mathrm{H}, \mathrm{aptd},{ }^{3} J_{\mathrm{HP}}=7.4,3 J_{\mathrm{HH}}=7.4,{ }^{4} J_{\mathrm{HH}}\right.$ $=1.3 \mathrm{~Hz}, o-\mathrm{Tol} H), 7.10-7.05(1 \mathrm{H}, \mathrm{m}, o-\mathrm{Tol} H), 7.01\left(1 \mathrm{H}, \mathrm{apt}, 3+3 J_{\mathrm{HH}}=\right.$ $7.4 \mathrm{~Hz}, o-\mathrm{Tol} H), 6.84-6.79(1 \mathrm{H}, \mathrm{m}, \mathrm{o}-\mathrm{Tol} H), 5.13(1 \mathrm{H}, \mathrm{brs}, \mathrm{Cp} H)$, $4.42\left(1 \mathrm{H}, \mathrm{apt},{ }^{3+3} \mathrm{JHH}_{\mathrm{HH}}=2.0 \mathrm{~Hz}, \mathrm{CpH}\right), 4.30\left(1 \mathrm{H}, \mathrm{apt},{ }^{2+3} J_{\mathrm{HH}}=8.9 \mathrm{~Hz}\right.$, $\mathrm{CHH}), 4.24(5 \mathrm{H}, \mathrm{s}, \mathrm{Cp} H), 3.92-3.86(1 \mathrm{H}, \mathrm{m}, \mathrm{CH}), 3.74\left(1 \mathrm{H}, \mathrm{apt},{ }^{2+3} J_{\mathrm{HH}}\right.$ $=8.1 \mathrm{~Hz}, \mathrm{CH} H), 3.59(1 \mathrm{H}, \mathrm{s}, \mathrm{Cp} H), 2.28\left(3 \mathrm{H}, \mathrm{d},{ }^{4} J_{\mathrm{HP}}=1.5 \mathrm{~Hz}, \mathrm{CH}_{3}\right)$, $1.71\left(1 \mathrm{H}\right.$, apoct, $\left.{ }^{3+3+3} \mathrm{JHH}_{\mathrm{HH}}=6.7 \mathrm{~Hz}, \mathrm{CH}\right), 0.85\left(3 \mathrm{H}, \mathrm{d},{ }^{3} J_{\mathrm{HH}}=6.8 \mathrm{~Hz}, \mathrm{CH}_{3}\right)$, $0.71\left(3 \mathrm{H}, \mathrm{d},{ }^{3} \mathrm{~J}_{\mathrm{HH}}=6.8 \mathrm{~Hz}, \mathrm{CH}\right) .{ }^{13} \mathrm{C}\left\{{ }^{1} \mathrm{H}\right\} \mathrm{NMR}\left(125 \mathrm{MHz} \mathrm{CDCl}_{3}\right)$ : $165.3(C=\mathrm{N}), 140.9\left(\mathrm{~d},{ }^{2} J_{\mathrm{CP}}=25.5 \mathrm{~Hz}, o\right.$-Tol $C$ ), $138.3\left(\mathrm{~d},{ }^{1} J_{\mathrm{CP}}=14.2\right.$ Hz, $o$-TolC), $137.3\left(\mathrm{~d},{ }^{1} J_{\mathrm{CP}}=12.5 \mathrm{~Hz}, \mathrm{PhC}\right), 134.9\left(\mathrm{~d},{ }^{2} J_{\mathrm{CP}}=21.1 \mathrm{~Hz}\right.$, $\mathrm{Ph} C$ ), 131.9 (o-TolC), $129.7\left(\mathrm{~d}, 3_{\mathrm{CP}}=4.5 \mathrm{~Hz}, o\right.$-Tol $C$ ), $129.1(\mathrm{Ph} C$ ), $128.4\left(\mathrm{~d},{ }^{3} \mathrm{JP}_{\mathrm{CP}}=7.1 \mathrm{~Hz}, \mathrm{Ph} C\right), 128.1(o-\mathrm{Tol} C), 125.7(o-\mathrm{Tol} C), 78.9(\mathrm{~d}$, $\left.{ }^{2} J_{\mathrm{CP}}=14.7 \mathrm{~Hz}, \mathrm{Cp} C\right), 75.8\left(\mathrm{~d},{ }^{1} J_{\mathrm{CP}}=16.6 \mathrm{~Hz}, \mathrm{Cp} C\right), 74.4\left(\mathrm{~d},{ }^{2} J_{\mathrm{CP}}=4.2\right.$ $\mathrm{Hz}, \mathrm{Cp} C), 72.4\left(\mathrm{~d},{ }^{3} J_{\mathrm{CP}}=1.9 \mathrm{~Hz}, \mathrm{Cp} C\right), 72.2(\mathrm{CH}), 71.0(\mathrm{Cp} C), 70.9(\mathrm{~d}$, $\left.{ }^{3} J_{\mathrm{CP}}=1.0 \mathrm{~Hz}, \mathrm{CpC}\right), 69.8\left(\mathrm{CH}_{2}\right), 32.4(\mathrm{CH}), 21.1\left(\mathrm{~d},{ }^{3} J_{\mathrm{CP}}=21.7 \mathrm{~Hz}, \mathrm{CH}_{3}\right)$, $18.8\left(\mathrm{CH}_{3}{ }^{\prime}\right), 17.8\left(\mathrm{CH}_{3}\right) .{ }^{31} \mathrm{P}\left\{{ }^{1} \mathrm{H}\right\}$ NMR $\left(202 \mathrm{MHz}, \mathrm{CDCl}_{3}\right):-23.90(\mathrm{Po}-$ TolPh). HRMS (ASAP-TOF) $m / z$ : $[\mathrm{M}+\mathrm{H}]^{+}$Calcd for $\mathrm{C}_{29} \mathrm{H}_{31} \mathrm{FeNOP}$ 496.1493; Found 496.1497.

\section{Preparation of $\quad(S)-2-\left[\left(S_{\mathrm{p}}\right)-2-\left(\left(S_{\text {phos }}\right)-o r t h o-t o l-\right.\right.$ ylphenylphosphino)ferrocenyl]-4-methyloxazoline,}

$\left(S, S_{\mathrm{p}}, \boldsymbol{S}_{\text {phos }}\right)$-L3b. $(S)-\mathbf{1 b}(0.120 \mathrm{~g}, 0.45 \mathrm{mmol})$ was added to a flame dried Schlenk tube under an inert atmosphere and dissolved in dry diethyl ether ( $5 \mathrm{~mL})$. TMEDA $(0.09 \mathrm{~mL}, 0.58 \mathrm{mmol})$ was added and solution was cooled to $-78{ }^{\circ} \mathrm{C}$ and stirred for $5 \mathrm{~min}$ after which $s$ butyllithium (1.4 $\mathrm{M}$ in hexanes) $(0.41 \mathrm{~mL}, 0.58 \mathrm{mmol}$ ) was slowly added. After stirring for 2 hours, dichlorophenylphosphine (85 $\mu$, $0.62 \mathrm{mmol}$ ) was added and the reaction allowed to stir at room temperature for $1 \mathrm{~h}$. The reaction was re-cooled to $-78{ }^{\circ} \mathrm{C}$ and $o$ tolylmagnesium bromide ( $2.0 \mathrm{M}$ in THF) $(0.31 \mathrm{~mL}, 0.62 \mathrm{mmol})$ was added and the reaction allowed to warm to room temperature and stir for an additional hour. The reaction was cooled to $0{ }^{\circ} \mathrm{C}$ quenched with saturated sodium carbonate solution and separated with diethyl ether, dried with magnesium sulphate and the solvent removed in vacuo. Purification by column chromatography ( $\mathrm{SiO}_{2}$, $30 \%$ EtOAc/hexane) yielded an orange solid (0.08 g, 39\%). $R_{\mathrm{f}} 0.2$ (30\% EtOAc/hexane). Mp $56-57{ }^{\circ} \mathrm{C} .[\alpha]_{\mathrm{D}}^{22.4^{\circ} \mathrm{C}}=+182(c 0.20$, $\mathrm{CHCl}_{3}$ ). IR (film): 3052, 3003, 2964, 2929, 2890, 1649 (CN). ${ }^{1} \mathrm{H}$ NMR (500 MHz, $\left.\mathrm{CDCl}_{3}\right): 7.29$ - $7.17(7 \mathrm{H}, \mathrm{m}, \mathrm{Ph} H+o-\mathrm{Tol} H), 7.08-6.98$ $(2 \mathrm{H}, \mathrm{m}, o-\mathrm{Tol} H), 4.95\left(1 \mathrm{H}, \mathrm{ddd},{ }^{3} J_{\mathrm{HH}}=2.4,{ }^{4} J_{\mathrm{HH}}=1.5,{ }^{4} J_{\mathrm{HP}}=0.5 \mathrm{~Hz}\right.$, $\mathrm{CpH}), 4.38-4.31(2 \mathrm{H}, \mathrm{m}, \mathrm{Cp} H+\mathrm{CHH}), 4.23(5 \mathrm{H}, \mathrm{s}, \mathrm{CpH}), 4.09-4.00$ $(1 \mathrm{H}, \mathrm{m}, \mathrm{CH}), 3.69\left(1 \mathrm{H}, \mathrm{ddd},{ }^{3} J_{\mathrm{HH}}=2.4,{ }^{3} J_{\mathrm{HP}}=1.4,4 J_{\mathrm{HH}}=0.8 \mathrm{~Hz}, \mathrm{Cp} H\right)$, $3.02\left(1 \mathrm{H}, \mathrm{dd},{ }^{2} \mathrm{~J}_{\mathrm{HH}}=9.0,3 \mathrm{~J}_{\mathrm{HH}}=8.1 \mathrm{~Hz}, \mathrm{CH}\right), 2.86\left(3 \mathrm{H}, \mathrm{s}, \mathrm{CH}_{3}\right), 1.03$ $\left(3 \mathrm{H}, \mathrm{d},{ }^{3} J_{\mathrm{HH}}=6.5 \mathrm{~Hz}, \mathrm{CH}_{3}\right) \cdot{ }^{13} \mathrm{C}\left\{{ }^{1} \mathrm{H}\right\} \mathrm{NMR}\left(125 \mathrm{MHz}, \mathrm{CDCl}_{3}\right): 166.1$ $(C=\mathrm{N}), 143.5\left(\mathrm{~d},{ }^{2} J_{\mathrm{CP}}=27.4 \mathrm{~Hz}, o-\mathrm{Tol} C\right), 140.4\left(\mathrm{~d},{ }^{1} J_{\mathrm{CP}}=12.8 \mathrm{~Hz}, \mathrm{Ph} C\right)$, $136.9\left(\mathrm{~d},{ }^{1} J_{\mathrm{CP}}=15.4 \mathrm{~Hz}, o-\mathrm{Tol} C\right), 135.8\left(\mathrm{~d},{ }^{2} J_{\mathrm{CP}}=3.3 \mathrm{~Hz}, o-\mathrm{Tol} C\right)$, $132.6\left(\mathrm{~d},{ }^{2} J_{\mathrm{CP}}=20.6 \mathrm{~Hz}, \mathrm{PhC}\right), 130.1\left(\mathrm{~d},{ }^{3} J_{\mathrm{CP}}=4.9 \mathrm{~Hz}, o-\mathrm{Tol} C\right), 129.2$ $(o-\mathrm{Tol} C), 128.2\left(\mathrm{~d}, 3 J_{\mathrm{CP}}=6.9 \mathrm{~Hz}, \mathrm{Ph} C\right), 127.9(\mathrm{Ph} C), 126.1\left(\mathrm{~d}, 3 J_{\mathrm{CP}}=\right.$ $2.0 \mathrm{~Hz}, o-\mathrm{Tol} C), 79.7\left(\mathrm{~d},{ }^{2} J_{\mathrm{CP}}=15.5 \mathrm{~Hz}, \mathrm{Cp} C\right), 74.6(\mathrm{Cp} C), 74.2(\mathrm{Cp} C+$ $\left.\mathrm{CH}_{2}\right), 71.2(\mathrm{Cp} C), 70.9\left(\mathrm{~d},{ }^{3} J_{\mathrm{CP}}=0.8 \mathrm{~Hz}, \mathrm{CpC}\right), 70.6(\mathrm{Cp} C), 61.5(\mathrm{CH})$, $22.2\left(\mathrm{~d},{ }^{3} J_{\mathrm{CP}}=22.7 \mathrm{~Hz}, \mathrm{CH}_{3}\right), 21.0\left(\mathrm{CH}_{3}\right) .{ }^{31} \mathrm{P}\left\{{ }^{1} \mathrm{H}\right\} \mathrm{NMR}(202 \mathrm{MHz}$, $\mathrm{CDCl}_{3}$ ): -25.89 (PPho-Tol). HRMS (ASAP-TOF) $\mathrm{m} / \mathrm{z}$ : $[\mathrm{M}+\mathrm{H}]^{+}$Calcd for $\mathrm{C}_{27} \mathrm{H}_{27} \mathrm{FeNOP} 468.1180$; Found = 468.1174.

\section{Preparation of $\quad(S)-2-\left[\left(S_{\mathrm{p}}\right)-2-\left(\left(R_{\mathrm{phos}}\right)-\right.\right.$ ortho-tol-} ylphenylphosphino)ferrocenyl]-4-methyloxazoline,

$\left(\boldsymbol{S}, \boldsymbol{S}_{\mathrm{p}}, \boldsymbol{R}_{\text {phos }}\right)$-L4b. $(S)$-1b $(0.120 \mathrm{~g}, 0.45 \mathrm{mmol})$ was added to a flame dried Schlenk tube under an inert atmosphere and dissolved in dry diethyl ether ( $5 \mathrm{~mL})$. TMEDA $(0.09 \mathrm{~mL}, 0.58 \mathrm{mmol})$ was added and solution was cooled to $-78{ }^{\circ} \mathrm{C}$ and stirred for 5 min after which $s$ - butyllithium (1.4 M in hexanes) $(0.41 \mathrm{~mL}, 0.58 \mathrm{mmol})$ was slowly added. After stirring for 2 hours, ortho-tolyldichlorophosphine (85 $\mu \mathrm{l}, 0.62 \mathrm{mmol}$ ) was added and the reaction allowed to stir at room temperature for $1 \mathrm{~h}$. The reaction was re-cooled to $-78^{\circ} \mathrm{C}$ and phenylmagnesium bromide (1.0 M in THF) ( $0.62 \mathrm{~mL}, 0.62 \mathrm{mmol}$ ) was added and the reaction allowed to warm to room temperature and stir for an additional hour. The reaction was cooled to $0{ }^{\circ} \mathrm{C}$ quenched with saturated sodium carbonate solution and separated with diethyl ether, dried with magnesium sulphate and the solvent removed in vacuo. Purification by column chromatography $\left(\mathrm{SiO}_{2}\right.$, $30 \% \mathrm{EtOAc} /$ hexane) yielded an orange solid (0.10 g, 49\%). $R_{\mathrm{f}} 0.3$

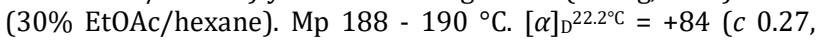
$\mathrm{CHCl}_{3}$ ). IR (film): 3049, 2961, 2904, 1642 (CN). ${ }^{1} \mathrm{H}$ NMR $(500 \mathrm{MHz}$, $\left.\mathrm{CDCl}_{3}\right): 7.49$ - $7.44(2 \mathrm{H}, \mathrm{m}, \mathrm{Ph} H), 7.39-7.33(3 \mathrm{H}, \mathrm{m}, \mathrm{PhH}), 7.16(1 \mathrm{H}$, apt, $\left.{ }^{3} J_{\mathrm{HH}}=6.8,{ }^{3} \mathrm{~J}_{\mathrm{HP}}=6.8 \mathrm{~Hz}, o-\mathrm{Tol} H\right), 7.11-7.06(1 \mathrm{H}, \mathrm{m}, o-\mathrm{Tol} H)$, $7.04\left(1 \mathrm{H}\right.$, apt, $\left.{ }^{3+3} \mathrm{~J}_{\mathrm{HH}}=7.4 \mathrm{~Hz}, o-\mathrm{Tol} H\right), 6.84\left(1 \mathrm{H}\right.$, apdd, ${ }^{3+3} \mathrm{JHH}_{\mathrm{HH}}=6.7$, $\left.{ }^{4} J_{\mathrm{HH}}=4.3 \mathrm{~Hz}, o-\mathrm{Tol} H\right), 5.03(1 \mathrm{H}, \mathrm{brs}, \mathrm{Cp} H), 4.43-4.34(2 \mathrm{H}, \mathrm{m}, \mathrm{Cp} H$ $+\mathrm{CHH}), 4.23(5 \mathrm{H}, \mathrm{s}, \mathrm{Cp} H), 4.15-4.03(1 \mathrm{H}, \mathrm{m}, \mathrm{CH}), 3.56(1 \mathrm{H}, \mathrm{brs}$, $\mathrm{CpH}), 3.39\left(1 \mathrm{H}, \mathrm{apt},{ }^{2+3} J_{\mathrm{HH}}=8.3 \mathrm{~Hz}, \mathrm{CH} H\right), 2.27(3 \mathrm{H}, \mathrm{s}, \mathrm{CH}), 1.13(1 \mathrm{H}$, $\left.\mathrm{d},{ }^{3} \mathrm{HH}_{\mathrm{HH}}=6.6 \mathrm{~Hz}, \mathrm{CH}\right) .{ }^{13} \mathrm{C}\left\{{ }^{1} \mathrm{H}\right\} \operatorname{NMR}\left(125 \mathrm{MHz}, \mathrm{CDCl}_{3}\right): 166.1(\mathrm{C}=\mathrm{N})$, $141.0\left(\mathrm{~d},{ }^{2} J_{\mathrm{CP}}=25.3 \mathrm{~Hz}, o-\mathrm{Tol} C\right), 138.2\left(\mathrm{~d},{ }^{1} J_{\mathrm{CP}}=14.3 \mathrm{~Hz}, o-\mathrm{Tol} C\right.$ ), $137.1\left(\mathrm{~d},{ }^{1} J_{\mathrm{CP}}=11.9 \mathrm{~Hz}, \mathrm{Ph} C\right), 134.8\left(\mathrm{~d},{ }^{2} J_{\mathrm{CP}}=21.0 \mathrm{~Hz}, \mathrm{PhC}\right), 131.7$ $(o$-Tol $C), 129.8\left(\mathrm{~d}, 3 J_{\mathrm{CP}}=4.4 \mathrm{~Hz}, o\right.$-TolC $), 129.1(\mathrm{Ph} C), 128.4\left(\mathrm{~d}, 3{ }^{3} \mathrm{CP}\right.$ $=7.3 \mathrm{~Hz}, \mathrm{Ph} C$ ), $128.1\left(o-\mathrm{Tol} C\right.$ ), 125.7 (o-TolC), $78.7\left(\mathrm{~d},{ }^{2} J_{\mathrm{CP}}=14.5\right.$ $\mathrm{Hz}, \mathrm{Cp} C$ ), $75.4\left(\mathrm{~d},{ }^{1} J_{\mathrm{CP}}=16.3 \mathrm{~Hz}, \mathrm{Cp} C\right), 74.5\left(\mathrm{~d},{ }^{3} J_{\mathrm{CP}}=3.8 \mathrm{~Hz}, \mathrm{Cp} C\right.$ ), $74.2\left(\mathrm{CH}_{2}\right), 72.4\left(\mathrm{~d},{ }^{3} \mathrm{CP}_{\mathrm{cP}}=1.8 \mathrm{~Hz}, \mathrm{CpC}\right), 71.2(\mathrm{CpC}), 70.9\left(\mathrm{~d},{ }^{3} J_{\mathrm{CP}}=0.9\right.$ $\mathrm{Hz}, \mathrm{CpC}), 61.7(\mathrm{CH}), 21.3\left(\mathrm{CH}_{3}\right), 21.1\left(\mathrm{CH}_{3}\right) .{ }^{31} \mathrm{P}\left\{{ }^{1} \mathrm{H}\right\} \mathrm{NMR}(202 \mathrm{MHz}$, $\left.\mathrm{CDCl}_{3}\right)$-23.32 (Po-TolPh). HRMS (ASAP-TOF) $\mathrm{m} / z$ : $[\mathrm{M}+\mathrm{H}]^{+} \mathrm{Calcd}$ for $\mathrm{C}_{27} \mathrm{H}_{27} \mathrm{FeNOP} 468.1180$; Found 468.1181.

Preparation of $(S)-2-\left[\left(R_{\mathrm{p}}\right)-2-\left(\left(S_{\mathrm{phos}}\right)\right.\right.$-butylortho-tolylphosphino)-5-deuteroferrocenyl]-4-(1-methylethyl)oxazoline, $\left(\boldsymbol{S}, \boldsymbol{R}_{\mathrm{p}}, \boldsymbol{S}_{\text {phos }}\right)-\mathbf{2 a}$. $(S)-2-d-\mathbf{1 a}^{15}(0.040 \mathrm{~g}, 0.13 \mathrm{mmol})$ was added to a flame dried Schlenk tube under an inert atmosphere and dissolved in dry THF $(1 \mathrm{~mL})$. The solution was cooled to $-78{ }^{\circ} \mathrm{C}$ and stirred for $5 \mathrm{~min}$ after which $s$-butyllithium (1.4 $\mathrm{M}$ in hexanes) $(0.13 \mathrm{~mL}, 0.17 \mathrm{mmol})$ was slowly added. After stirring for 2 hours, ortho-tolyldichlorophosphine $(27.5 \mu \mathrm{l}, 0.19 \mathrm{mmol})$ was added and the reaction allowed to stir at room temperature for $1 \mathrm{~h}$. The reaction was re-cooled to $-78{ }^{\circ} \mathrm{C}$ and butylmagnesium chloride $(2.0 \mathrm{M}$ in THF) $(0.09 \mathrm{~mL}, 0.19 \mathrm{mmol})$ was added and the reaction allowed to warm to room temperature and stir for an additional hour. The reaction was cooled to $0{ }^{\circ} \mathrm{C}$ quenched with saturated sodium carbonate solution and separated with diethyl ether, dried with magnesium sulphate and the solvent removed in vacuo. Purification by column chromatography $\left(\mathrm{SiO}_{2}, 10 \% \mathrm{EtOAc} /\right.$ hexane) yielded an orange oil $(0.038 \mathrm{~g}, 59 \%) . R_{\mathrm{f}} 0.2(10 \% \mathrm{EtOAc} /$ hexane $) \cdot[\alpha]_{\mathrm{D}}^{23.5^{\circ} \mathrm{C}}=-$ 153 (c 0.16, $\mathrm{CHCl}_{3}$ ). IR (film): 3056, 2957, 2929, 2873, 1656 (CN). ${ }_{1} \mathrm{H}$ NMR $\left(500 \mathrm{MHz}, \mathrm{CDCl}_{3}\right): 7.07-7.05(2 \mathrm{H}, \mathrm{m}, o-\mathrm{Tol} H), 6.97-6.89$ $(2 \mathrm{H}, \mathrm{m}, o-\mathrm{Tol} H), 4.53\left(1 \mathrm{H}, \mathrm{d},{ }^{3} J_{\mathrm{HH}}=2.5 \mathrm{~Hz}, \mathrm{Cp} H\right), 4.51\left(1 \mathrm{H}, \mathrm{d},{ }^{3}\right)_{\mathrm{HH}}=$ $2.4 \mathrm{~Hz}, \mathrm{CpH}), 4.25(5 \mathrm{H}, \mathrm{s}, \mathrm{CpH}), 4.01\left(1 \mathrm{H}, \mathrm{dd},{ }^{2} J_{\mathrm{HH}}=9.7,{ }^{3} J_{\mathrm{HH}}=8.2 \mathrm{~Hz}\right.$, $\mathrm{CHH}), 3.95\left(1 \mathrm{H}, \mathrm{apt},{ }^{2+3} \mathrm{JHH}_{\mathrm{HH}}=7.4 \mathrm{~Hz}, \mathrm{CH}\right), 3.89-3.84(1 \mathrm{H}, \mathrm{m}, \mathrm{CH})$, $2.63\left(3 \mathrm{H}, \mathrm{d},{ }^{4} \mathrm{JP}_{\mathrm{HP}}=1.1 \mathrm{~Hz}, \mathrm{CH} \mathrm{H}_{3}\right), 2.04-1.96(1 \mathrm{H}, \mathrm{m}, \mathrm{CHH}), 1.83-1.76$ $(1 \mathrm{H}, \mathrm{m}, \mathrm{CH} H), 1.66-1.56\left(2 \mathrm{H}, \mathrm{m}, \mathrm{CH}+\mathrm{CH} \mathrm{H}^{\prime}\right), 0.51-1.42(3 \mathrm{H}, \mathrm{m}$, $\left.\left.\mathrm{CH}+\mathrm{CH}_{2}\right), 0.93(3 \mathrm{H}, \mathrm{t}, 3)_{\mathrm{HH}}=7.2 \mathrm{~Hz}, \mathrm{CH}_{3}\right), 0.70\left(3 \mathrm{H}, \mathrm{d},{ }^{3} J_{\mathrm{HH}}=6.8\right.$ $\left.\mathrm{Hz}, \mathrm{CH}_{3}\right), 0.66\left(3 \mathrm{H}, \mathrm{d},{ }^{3} \mathrm{~J}_{\mathrm{HH}}=6.8 \mathrm{~Hz}, \mathrm{CH}_{3}\right) .{ }^{13} \mathrm{C}\left\{{ }^{1} \mathrm{H}\right\} \mathrm{NMR}(125 \mathrm{MHz}$, $\left.\mathrm{CDCl}_{3}\right): 165.1(C=\mathrm{N}), 142.1\left(\mathrm{~d},{ }^{2} \mathrm{JP}_{\mathrm{CP}}=27.8 \mathrm{~Hz}, o-\mathrm{Tol} C\right), 140.5\left(\mathrm{~d},{ }^{1} J_{\mathrm{CP}}\right.$ $=17.3 \mathrm{~Hz}, o-\mathrm{Tol} C), 131.5\left(\mathrm{~d},{ }^{2} \mathrm{CP}=2.0 \mathrm{~Hz}, o-\mathrm{Tol} C\right), 129.3\left(\mathrm{~d},{ }^{3} J_{\mathrm{CP}}=\right.$ $5.4 \mathrm{~Hz}, o$-TolC), $128.0(o$-TolC $), 125.8(o$-TolC $), 79.9\left(\mathrm{~d},{ }^{2} J_{\mathrm{CP}}=16.7\right.$ $\mathrm{Hz}, \mathrm{CpC}), 74.7(\mathrm{Cp} C), 72.1(\mathrm{CH}), 71.5\left(\mathrm{~d},{ }^{2} J_{\mathrm{CP}}=3.4 \mathrm{~Hz}, \mathrm{CpC}\right), 70.8$ (CpC), $70.4(\mathrm{CpC}), 69.3\left(\mathrm{CH}_{2}\right), 32.4(\mathrm{CH}), 29.0\left(\mathrm{~d},{ }^{2} J_{\mathrm{CP}}=1.8 \mathrm{~Hz}, \mathrm{CH}_{2}\right)$, $28.8\left(\mathrm{~d},{ }^{1} J_{\mathrm{CP}}=4.9 \mathrm{~Hz}, \mathrm{CH}_{2}\right), 24.7\left(\mathrm{~d},{ }^{3} \mathrm{CP}_{\mathrm{CP}}=12.5 \mathrm{~Hz}, \mathrm{CH}_{2}\right), 21.9\left(\mathrm{~d},{ }^{3}\right)_{\mathrm{CP}}$ $\left.=23.1 \mathrm{~Hz}, \mathrm{CH}_{3}\right), 18.3\left(\mathrm{CH}_{3}\right), 17.8\left(\mathrm{CH}_{3}\right), 14.0\left(\mathrm{CH}_{3}\right) .{ }^{31} \mathrm{P}\left\{{ }^{1} \mathrm{H}\right\} \mathrm{NMR}$ (202 $\mathrm{MHz}, \mathrm{CDCl}_{3}$ ): -40.38 (Po-TolBu). HRMS (ASAP-TOF) $\mathrm{m} / \mathrm{z}$ : $[\mathrm{M}+\mathrm{H}]^{+}$Calcd for $\mathrm{C}_{27} \mathrm{H}_{34} \mathrm{DFeNOP}$ 477.1869; Found 477.1866.

\section{Preparation of $(S)-2-\left[\left(R_{\mathrm{p}}\right)-2-\left(\left(R_{\mathrm{phos}}\right)-\right.\right.$ ortho-tol-} ylphenylphosphino)-5-deuteroferrocenyl]-4-(1-meth-

ylethyl)oxazoline, $\left(\boldsymbol{S}, \boldsymbol{R}_{\mathrm{p}}, \boldsymbol{R}_{\text {phos }}\right)$-2- $\boldsymbol{d}$-L5a. $(S)-2-d-1 \mathrm{a}(0.073 \mathrm{~g}, 0.25$ $\mathrm{mmol}$ ) was added to a flame dried Schlenk tube under an inert atmosphere and dissolved in dry THF ( $3 \mathrm{~mL})$. The solution was 
cooled to $-78{ }^{\circ} \mathrm{C}$ and stirred for 5 min after which s-butyllithium (1.4 $\mathrm{M}$ in hexanes) $(0.23 \mathrm{~mL}, 0.32 \mathrm{mmol})$ was slowly added. After stirring for 2 hours, dichlorophenylphosphine $(47 \mu \mathrm{l}, 0.34 \mathrm{mmol})$ was added and the reaction allowed to stir at room temperature for $1 \mathrm{~h}$. The reaction was re-cooled to $-78^{\circ} \mathrm{C}$ and ortho-tolylmagnesium bromide ( $2.0 \mathrm{M}$ in THF) ( $0.17 \mathrm{~mL}, 0.34 \mathrm{mmol})$ was added and the reaction allowed to warm to room temperature and stir for an additional hour. The reaction was cooled to $0{ }^{\circ} \mathrm{C}$ quenched with saturated sodium carbonate solution and separated with diethyl ether, dried with magnesium sulphate and the solvent removed in vacuo. Purification by column chromatography $\left(\mathrm{SiO}_{2}, 10 \%\right.$ EtOAc/hexane) yielded an orange solid $(0.07 \mathrm{~g}, 59 \%) . R_{\mathrm{f}} 0.2(10 \%$ EtOAc/hexane). Mp $100-101^{\circ} \mathrm{C} .[\alpha]_{\mathrm{D}} 225^{\circ} \mathrm{C}=-80\left(c 0.22, \mathrm{CHCl}_{3}\right)$. IR (film): 3052, 2957, 2873, 1656 (CN). ${ }^{1} \mathrm{H}$ NMR (500 MHz, $\left.\mathrm{CDCl}_{3}\right)$ : 7.28 - $7.22(2 \mathrm{H}, \mathrm{m}, o-\mathrm{Tol} H), 7.21-7.13(5 \mathrm{H}, \mathrm{m}, \mathrm{PhH}), 7.08-7.02(2 \mathrm{H}$, m, $o-\mathrm{Tol} H), 4.37\left(1 \mathrm{H}, \mathrm{d},{ }^{3} J_{\mathrm{HH}}=2.4 \mathrm{~Hz}, \mathrm{Cp} H\right), 4.20(5 \mathrm{H}, \mathrm{s}, \mathrm{Cp} H), 3.99$ $\left(1 \mathrm{H}, \mathrm{dd},{ }^{2} J_{\mathrm{HH}}=7.0,{ }^{3} J_{\mathrm{HH}}=5.0 \mathrm{~Hz}, \mathrm{CHH}\right), 3.87-3.75(2 \mathrm{H}, \mathrm{m}, \mathrm{CH}+\mathrm{CH} H)$, $3.71\left(1 \mathrm{H}, \mathrm{d},{ }^{3} \mathrm{~J}_{\mathrm{HH}}=2.3 \mathrm{~Hz}, \mathrm{CpH}\right), 2.84\left(3 \mathrm{H}, \mathrm{s}, \mathrm{CH}_{3}\right), 1.57(1 \mathrm{H}$, apoct, $3+3+3 \mathrm{~J}=5.9 \mathrm{~Hz}, \mathrm{CH}), 0.72\left(3 \mathrm{H}, \mathrm{d},{ }^{3} \mathrm{HH}_{\mathrm{HH}}=6.8 \mathrm{~Hz}, \mathrm{CH}_{3}\right), 0.71\left(3 \mathrm{H}, \mathrm{d},{ }^{3} \mathrm{HH}_{\mathrm{HH}}\right.$ $\left.=6.8 \mathrm{~Hz}, \mathrm{CH}_{3}\right) \cdot{ }^{13} \mathrm{C}\left\{{ }^{1} \mathrm{H}\right\} \operatorname{NMR}\left(125 \mathrm{MHz}, \mathrm{CDCl}_{3}\right): 165.1(\mathrm{C}=\mathrm{N}), 143.7$ $\left(\mathrm{d},{ }^{2} J_{\mathrm{CP}}=26.6 \mathrm{~Hz}, o\right.$-TolC), $140.7\left(\mathrm{~d},{ }^{1} J_{\mathrm{CP}}=12.4 \mathrm{~Hz}, \mathrm{PhC}\right.$ ), 137.0 (d, ${ }^{1} J_{\mathrm{CP}}=15.5 \mathrm{~Hz}, o-\mathrm{Tol} C$ ), $136.5\left(\mathrm{~d},{ }^{2} J_{\mathrm{CP}}=4.9 \mathrm{~Hz}, o-\mathrm{Tol} C\right), 132.3\left(\mathrm{~d},{ }^{2} J_{\mathrm{CP}}\right.$ $=20.0 \mathrm{~Hz}, \mathrm{Ph} C), 130.1\left(\mathrm{~d},{ }^{3} \mathrm{CP}=4.8 \mathrm{~Hz}, o-\mathrm{Tol} C\right), 129.2(o-\mathrm{Tol} C)$, $128.0\left(\mathrm{~d},{ }^{3} \mathrm{CP}=6.7 \mathrm{~Hz}, \mathrm{PhC}\right), 127.6(\mathrm{Ph} C), 126.0\left(\mathrm{~d},{ }^{3} \mathrm{CP}=2.5 \mathrm{~Hz}, o_{-}\right.$ $\mathrm{Tol} C$ ), $79.0\left(\mathrm{~d},{ }^{2} \mathrm{JP}_{\mathrm{CP}}=15.3 \mathrm{~Hz}, \mathrm{Cp} C\right), 74.4\left(\mathrm{~d},{ }^{2} J_{\mathrm{CP}}=2.8 \mathrm{~Hz}, \mathrm{Cp} C\right), 72.1$ $(\mathrm{CH}), 72.0\left(\mathrm{~d},{ }^{1} J_{\mathrm{CP}}=20.8 \mathrm{~Hz}, \mathrm{CpC}\right), 70.8(\mathrm{CpC}), 70.3(\mathrm{CpC}), 69.5\left(\mathrm{CH}_{2}\right)$, $32.5(\mathrm{CH}), 22.4\left(\mathrm{~d},{ }^{3} \mathrm{CP}_{\mathrm{CP}}=22.2 \mathrm{~Hz}, \mathrm{CH}_{3}\right), 18.3\left(\mathrm{CH}_{3}\right), 17.9\left(\mathrm{CH}_{3}\right)$. ${ }^{31} \mathrm{P}\left\{{ }^{1} \mathrm{H}\right\}$ NMR (202 MHz, $\left.\mathrm{CDCl}_{3}\right):-26.69$ (PPho-Tol). HRMS (ASAPTOF) $m / z:[\mathrm{M}+\mathrm{H}]^{+}$Calcd for $\mathrm{C}_{29} \mathrm{H}_{30} \mathrm{DFeNOP}$ 497.1556; Found 497.1556.

\section{Preparation of $\quad(S)-2-\left[\left(R_{\mathrm{p}}\right)-2-\left(\left(S_{\text {phos }}\right)\right.\right.$-ortho-tol-} ylphenylphosphino)-5-deuteroferrocenyl]-4-(1-methylethyl)oxazoline, $\left(\boldsymbol{S}, \boldsymbol{R}_{\mathrm{p}}, \boldsymbol{S}_{\text {phos }}\right)-\mathbf{2}-\boldsymbol{d}$-L6a. $(S)-2-d-1 \mathrm{a}^{15}(0.100 \mathrm{~g}$, $0.34 \mathrm{mmol}$ ) was added to a flame dried Schlenk tube under an inert atmosphere and dissolved in dry THF $(4 \mathrm{~mL})$. The solution was cooled to $-78{ }^{\circ} \mathrm{C}$ and stirred for $5 \mathrm{~min}$ after which $s$-butyllithium (1.4 $\mathrm{M}$ in hexanes) $(0.31 \mathrm{~mL}, 0.44 \mathrm{mmol})$ was slowly added. After stirring for 2 hours, ortho-tolyldichlorophosphine $(63 \mu \mathrm{l}, 0.47$ $\mathrm{mmol}$ ) was added and the reaction allowed to stir at room temperature for $1 \mathrm{~h}$. The reaction was re-cooled to $-78{ }^{\circ} \mathrm{C}$ and phenylmagnesium bromide $(1.0 \mathrm{M}$ in THF) $(0.47 \mathrm{~mL}, 0.47 \mathrm{mmol})$ was added and the reaction allowed to warm to room temperature and stir for an additional hour. The reaction was cooled to $0{ }^{\circ} \mathrm{C}$ quenched with saturated sodium carbonate solution and separated with diethyl ether, dried with magnesium sulphate and the solvent removed in vacuo. Purification by column chromatography $\left(\mathrm{SiO}_{2}\right.$, $10 \%$ EtOAc /hexane) yielded an orange solid ( $0.10 \mathrm{~g}, 58 \%) . R_{\mathrm{f}} 0.3$

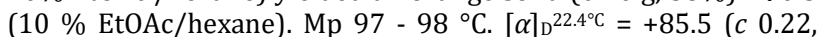
$\mathrm{CHCl}_{3}$ ). IR (film): 3052, 2954, 2873, 1656 (CN). ${ }^{1} \mathrm{H}$ NMR (500 MHz, $\left.\mathrm{CDCl}_{3}\right): 7.49\left(2 \mathrm{H}, \mathrm{aptd},{ }^{3} \mathrm{HH}_{\mathrm{HH}}=7.3,3{ }_{\mathrm{HP}}=7.3,{ }^{4} \mathrm{HH}_{\mathrm{HH}}=2.2 \mathrm{~Hz}, \mathrm{Ph} H\right), 7.38$ - $7.34(3 \mathrm{H}, \mathrm{m}, \mathrm{Ph} H), 7.13\left(1 \mathrm{H}\right.$, aptd, ${ }^{3} J_{\mathrm{HH}}=7.4,{ }^{3} \mathrm{JPP}_{\mathrm{HP}}=7.4,4{ }^{4} \mathrm{HH}=1.3$ $\mathrm{Hz}, o-\mathrm{Tol} H), 7.08-7.04(1 \mathrm{H}, \mathrm{m}, o-\mathrm{Tol} H), 6.99\left(1 \mathrm{H}, \mathrm{apt},{ }^{3+3}\right)_{\mathrm{HH}}=7.7$ $\mathrm{Hz}, o-\mathrm{Tol} H), 6.78\left(1 \mathrm{H}, \mathrm{ddd},{ }^{3} \mathrm{JHH}_{\mathrm{HH}}=7.6,{ }^{4} J_{\mathrm{HH}}=4.3,{ }^{5} \mathrm{JP}_{\mathrm{HP}}=1.1 \mathrm{~Hz}, o-\right.$ $\mathrm{Tol} H), 4.37\left(1 \mathrm{H}, \mathrm{d}, 3 \mathrm{~J}_{\mathrm{HH}}=2.5 \mathrm{~Hz}, \mathrm{Cp} H\right), 4.23(5 \mathrm{H}, \mathrm{s}, \mathrm{Cp} H), 4.08(1 \mathrm{H}$, $\left.\mathrm{dd},{ }^{3} J_{\mathrm{HH}}=9.6,{ }^{2} J_{\mathrm{HH}}=8.2 \mathrm{~Hz}, \mathrm{CHH}\right), 3.98\left(1 \mathrm{H}, \mathrm{dd},{ }^{2} J_{\mathrm{HH}}=8.2,{ }^{3} J_{\mathrm{HH}}=6.6\right.$ $\mathrm{Hz}, \mathrm{CH} H), 3.90\left(1 \mathrm{H}, \mathrm{apdt},{ }^{3+3} J_{\mathrm{HH}}=9.6,{ }^{3} \mathrm{~J}_{\mathrm{HH}}=6.2 \mathrm{~Hz}, \mathrm{CH}\right), 3.57(1 \mathrm{H}$, $\left.\mathrm{dd},{ }^{3} J_{\mathrm{HH}}=2.5,{ }^{2} J_{\mathrm{HH}}=0.6 \mathrm{~Hz}, \mathrm{CpH}\right), 2.29\left(3 \mathrm{H}, \mathrm{d},{ }^{4} J_{\mathrm{HP}}=1.4 \mathrm{~Hz}, \mathrm{CH}_{3}\right)$, $1.48\left(1 \mathrm{H}\right.$, apoct, $\left.{ }^{3+3+3} \mathrm{JHH}_{\mathrm{HH}}=6.3 \mathrm{~Hz}, \mathrm{CH}\right), 0.64\left(3 \mathrm{H}, \mathrm{d}^{3} \mathrm{~J}_{\mathrm{HH}}=6.8 \mathrm{~Hz}, \mathrm{CH}_{3}\right)$, $0.59\left(3 \mathrm{H}, \mathrm{d},{ }^{3} \mathrm{JHH}_{\mathrm{HH}}=6.8 \mathrm{~Hz}, \mathrm{CH} 3\right) \cdot{ }^{13} \mathrm{C}\left\{{ }^{1} \mathrm{H}\right\}$ NMR $\left(125 \mathrm{MHz}, \mathrm{CDCl}_{3}\right):$ $164.7\left(\mathrm{~d},{ }^{3} J_{\mathrm{CP}}=3.6 \mathrm{~Hz}, C=\mathrm{N}\right), 141.0\left(\mathrm{~d},{ }^{2} J_{\mathrm{CP}}=25.4 \mathrm{~Hz}, o-\mathrm{Tol} C\right), 138.1$ (d, ${ }^{1} J_{\mathrm{CP}}=12.8 \mathrm{~Hz}, o$-TolC), $137.4\left(\mathrm{~d},{ }^{1} J_{\mathrm{CP}}=12.2 \mathrm{~Hz}, \mathrm{PhC}\right.$ ), 135.0 (d, $\left.{ }^{2} J_{\mathrm{CP}}=20.8 \mathrm{~Hz}, \mathrm{PhC}\right), 131.8(o-\mathrm{Tol} C), 129.7\left(\mathrm{~d},{ }^{3} J_{\mathrm{CP}}=4.7 \mathrm{~Hz}, o-\mathrm{Tol} C\right)$, $129.0(\mathrm{Ph} C), 128.3\left(\mathrm{~d},{ }^{3} \mathrm{CP}_{\mathrm{CP}}=7.2 \mathrm{~Hz}, \mathrm{Ph} C\right), 128.0(o-\mathrm{Tol} C), 125.5(o-$ $\mathrm{Tol} C$ ), $78.6\left(\mathrm{~d},{ }^{2} J_{\mathrm{CP}}=13.5 \mathrm{~Hz}, \mathrm{Cp} C\right), 75.3\left(\mathrm{~d},{ }^{1} J_{\mathrm{CP}}=16.1 \mathrm{~Hz}, \mathrm{Cp} C\right), 74.6$ $\left(\mathrm{d},{ }^{2} J_{\mathrm{CP}}=4.4 \mathrm{~Hz}, \mathrm{Cp} C\right), 72.3(\mathrm{CH}), 70.8(\mathrm{CpC}), 70.6(\mathrm{CpC}), 69.8\left(\mathrm{CH}_{2}\right)$, $32.8(\mathrm{CH}), 21.1\left(\mathrm{~d},{ }^{3} \mathrm{JP}_{\mathrm{CP}}=21.7 \mathrm{~Hz}, \mathrm{CH}_{3}\right), 18.2\left(\mathrm{CH}_{3}\right), 17.9\left(\mathrm{CH}_{3}\right)$. ${ }^{31} \mathrm{P}\left\{{ }^{1} \mathrm{H}\right\}$ NMR $\left(202 \mathrm{MHz}, \mathrm{CDCl}_{3}\right):-24.70(\mathrm{Po}-\mathrm{TolPh})$. HRMS (ASAPTOF) $m / z:[\mathrm{M}+\mathrm{H}]^{+}$Calcd for $\mathrm{C}_{29} \mathrm{H}_{30} \mathrm{DFeNOP}$ 497.1556; Found 497.1557.
Preparation of $\quad(S)-2-\left[\left(R_{\mathrm{p}}\right)-2-\left(\left(R_{\mathrm{phos}}\right)\right.\right.$-ortho-tolylphenylphosphino)-5-deuteroferrocenyl]-4-methyloxazoline, $\left(\boldsymbol{S}, \boldsymbol{R}_{\mathbf{p}}, \boldsymbol{R}_{\text {phos }}\right)$-2- $\boldsymbol{d}$-L5b. $(S)-2-d-1 b^{15}(0.100 \mathrm{~g}, 0.37 \mathrm{mmol})$ was added to a flame dried Schlenk tube under an inert atmosphere and dissolved in dry diethyl ether $(5 \mathrm{~mL})$. The solution was cooled to $78^{\circ} \mathrm{C}$ and stirred for $5 \mathrm{~min}$ after which $s$-butyllithium $(1.4 \mathrm{M}$ in hexanes) ( $0.34 \mathrm{~mL}, 0.48 \mathrm{mmol}$ ) was slowly added. After stirring for 2 hours, dichlorophenylphosphine $(70 \mu \mathrm{l}, 0.52 \mathrm{mmol})$ was added and the reaction allowed to stir at room temperature for $1 \mathrm{~h}$. The reaction was re-cooled to $-78^{\circ} \mathrm{C}$ and $o$-tolylmagnesium bromide $(2.0 \mathrm{M}$ in THF) $(0.26 \mathrm{~mL}, 0.52 \mathrm{mmol})$ was added and the reaction allowed to warm to room temperature and stir for an additional hour. The reaction was cooled to $0^{\circ} \mathrm{C}$ quenched with saturated sodium carbonate solution and separated with diethyl ether, dried with magnesium sulphate and the solvent removed in vacuo. Purification by column chromatography $\left(\mathrm{SiO}_{2}, 30 \% \mathrm{EtOAc} /\right.$ hexane $)$ yielded an orange oil $(0.04 \mathrm{~g}, 17 \%) . R_{\mathrm{f}} 0.2\left(30 \% \mathrm{EtOAc} /\right.$ hexane). $[\alpha]_{\mathrm{D}} 235^{\circ} \mathrm{C}=-67$ (c 0.60, $\mathrm{CHCl}_{3}$ ). IR (film): 3052, 2962, 2923, 2873, 1652 (CN). ${ }^{1} \mathrm{H}$ NMR (500 MHz, $\left.\mathrm{CDCl}_{3}\right): 7.27$ - $7.22(2 \mathrm{H}, \mathrm{m}, o-\mathrm{Tol} H), 7.20$ - $7.14(5 \mathrm{H}$, $\mathrm{m}, \mathrm{Ph} H), 7.07-7.04(2 \mathrm{H}, \mathrm{m}, o-\mathrm{Tol} H), 4.37\left(1 \mathrm{H}, \mathrm{d},{ }^{3} J_{\mathrm{HH}}=2.5 \mathrm{~Hz}, \mathrm{Cp} H\right)$, $4.20(5 \mathrm{H}, \mathrm{s}, \mathrm{CpH}), 4.08-4.02(1 \mathrm{H}, \mathrm{m}, \mathrm{CH}), 3.91-3.86(1 \mathrm{H}, \mathrm{m}, \mathrm{CH})$, $3.79\left(1 \mathrm{H}, \mathrm{dd},{ }^{2} \mathrm{~J}_{\mathrm{HH}}=8.0,{ }^{3} J_{\mathrm{HH}}=5.8 \mathrm{~Hz}, \mathrm{CH}\right), 3.70\left(1 \mathrm{H}, \mathrm{dd},{ }^{3} J_{\mathrm{HH}}=2.5\right.$, $\left.{ }^{4} J_{\mathrm{HH}}=0.7 \mathrm{~Hz}, \mathrm{CpH}\right), 2.85(3 \mathrm{H}, \mathrm{s}, \mathrm{CH}), 0.96\left(3 \mathrm{H}, \mathrm{d},{ }^{3} \mathrm{JHH}_{\mathrm{HH}}=6.6 \mathrm{~Hz}, \mathrm{CH}_{3}\right)$. ${ }^{13} \mathrm{C}\left\{{ }^{1} \mathrm{H}\right\}$ NMR $(125 \mathrm{MHz}, \mathrm{CDCl} 3): 165.3\left(\mathrm{~d},{ }^{3} \mathrm{CP}_{\mathrm{CP}}=2.9 \mathrm{~Hz}, \mathrm{C}=\mathrm{N}\right), 143.6$ (d, ${ }^{2} J_{\mathrm{CP}}=27.0 \mathrm{~Hz}, o-\mathrm{Tol} C$ ), 140.7 (d, ${ }^{1} \mathrm{JP}_{\mathrm{CP}}=12.4 \mathrm{~Hz}, \mathrm{PhC}$ ), 136.9 (d, $\left.{ }^{1} J \mathrm{CP}=15.4 \mathrm{~Hz}, o-\mathrm{Tol} C\right), 136.4\left(\mathrm{~d},{ }^{2} J \mathrm{CP}=4.3 \mathrm{~Hz}, o-\mathrm{Tol} C\right), 132.3\left(\mathrm{~d},{ }^{2} J_{\mathrm{CP}}\right.$ $=20.2 \mathrm{~Hz}, \mathrm{Ph} C$ ), 130.1 (d, $\left.{ }^{3} \mathrm{CP}_{\mathrm{CP}}=4.7 \mathrm{~Hz}, o-\mathrm{Tol} C\right), 129.2(o-\mathrm{Tol} C)$, $128.0\left(\mathrm{~d},{ }^{3} \mathrm{JP}=6.7 \mathrm{~Hz}, \mathrm{PhC}\right), 127.5(\mathrm{PhC}), 126.0\left(\mathrm{~d},{ }^{3} J_{\mathrm{CP}}=2.2 \mathrm{~Hz}, o^{-}\right.$ TolC), $79.4\left(\mathrm{~d},{ }^{2} \mathrm{JP}_{\mathrm{CP}}=15.7 \mathrm{~Hz}, \mathrm{Cp} C\right), 74.4(\mathrm{Cp} C), 74.3\left(\mathrm{~d},{ }^{1} \mathrm{~J}_{\mathrm{CP}}=10.3\right.$ $\mathrm{Hz}, \mathrm{CpC}), 73.6\left(\mathrm{CH}_{2}\right), 70.9(\mathrm{Cp} C), 70.4(\mathrm{Cp} C), 61.6(\mathrm{CH}), 22.3\left(\mathrm{~d},{ }^{3}\right)_{\mathrm{CP}}$ $\left.=22.4 \mathrm{~Hz}, \mathrm{CH}_{3}\right), 21.3\left(\mathrm{CH}_{3}\right) .{ }^{31} \mathrm{P}\left\{{ }^{1} \mathrm{H}\right\}$ NMR $\left(202 \mathrm{MHz}, \mathrm{CDCl}_{3}\right):-26.51$ (PPho-Tol). HRMS (ASAP-TOF) $\mathrm{m} / \mathrm{z}: \quad[\mathrm{M}+\mathrm{H}]^{+}$Calcd for $\mathrm{C}_{27} \mathrm{H}_{26}$ DFeNOP 469.1243; Found 469.1242.

Preparation of $(S)-2-\left[\left(R_{\mathrm{p}}\right)-2-\left(\left(S_{\mathrm{phos}}\right)\right.\right.$-ortho-tolylphenylphosphino)-5-deuteroferrocenyl]-4-methyloxazo-

line, $\left(\boldsymbol{S}, \boldsymbol{R}_{\mathrm{p}}, \boldsymbol{S}_{\text {phos }}\right)$-2- $\boldsymbol{d}$-L6b. $(S)-2-d-\mathbf{1} \mathbf{b}^{15}(0.100 \mathrm{~g}, 0.37 \mathrm{mmol})$ was added to a flame dried Schlenk tube under an inert atmosphere and dissolved in dry tetrahydrofuran $(4 \mathrm{~mL})$. The solution was cooled to $-78^{\circ} \mathrm{C}$ and stirred for $5 \mathrm{~min}$ after which s-butyllithium (1.4 $\mathrm{M}$ in hexanes) ( $0.34 \mathrm{~mL}, 0.48 \mathrm{mmol}$ ) was slowly added. After stirring for 2 hours, ortho-tolyldichlorophosphine $(76 \mu \mathrm{l}, 0.52 \mathrm{mmol})$ was added and the reaction allowed to stir at room temperature for 1 $\mathrm{h}$. The reaction was re-cooled to $-78^{\circ} \mathrm{C}$ and phenylmagnesium bromide $(1.0 \mathrm{M}$ in THF) $(0.52 \mathrm{~mL}, 0.52 \mathrm{mmol})$ was added and the reaction allowed to warm to room temperature and stir for an additional hour. The reaction was cooled to $0{ }^{\circ} \mathrm{C}$ quenched with saturated sodium carbonate solution and separated with diethyl ether, dried with magnesium sulphate and the solvent removed in vacuo. Purification by column chromatography $\left(\mathrm{SiO}_{2}, 30 \%\right.$ EtOAc in Hexane) yielded an orange solid as a 16:1 ratio of diastereoisomers $(0.055 \mathrm{~g}, 32 \%)$. This was then recrystallized by dissolving in a minimum amount of dichloromethane and layering hexane on top and allowing to stand for 2 days in the freezer to give orange crystals (0.05 g, 29\%): $R_{\mathrm{f}} 0.3$ (30\% EtOAc/hexane). Mp $178-179{ }^{\circ} \mathrm{C}$. $[\alpha]_{\mathrm{D}}{ }^{24.3^{\circ} \mathrm{C}}=-14\left(c 0.56, \mathrm{CHCl}_{3}\right)$. IR (film): 3051, 2965, 2897, 1650 (CN). ${ }^{1} \mathrm{H}$ NMR (500 MHz, $\left.\mathrm{CDCl}_{3}\right): 7.51-7.45(2 \mathrm{H}, \mathrm{m}, \mathrm{PhH}), 7.38-$ $7.33(3 \mathrm{H}, \mathrm{m}, \mathrm{Ph} H), 7.15\left(1 \mathrm{H}\right.$, aptd, $\left.{ }^{3+3} \mathrm{~J}_{\mathrm{HH}}=7.4,{ }^{4} J_{\mathrm{HH}}=1.4 \mathrm{~Hz}, o-\mathrm{Tol} H\right)$, $7.09-7.05(1 \mathrm{H}, \mathrm{m}, o-\mathrm{Tol} H), 7.01\left(1 \mathrm{H}, \mathrm{apdd},{ }^{3+3} 3_{\mathrm{HH}}=11.3,{ }^{4} J_{\mathrm{HH}}=4.1\right.$ $\mathrm{Hz}, o-\mathrm{Tol} H), 6.80\left(1 \mathrm{H}, \mathrm{ddd},{ }^{3} \mathrm{HH}_{\mathrm{HH}}=7.6,{ }^{3} \mathrm{JP}_{\mathrm{HP}}=4.3,{ }^{4} J_{\mathrm{HH}}=1.2 \mathrm{~Hz}, o-\right.$ $\mathrm{Tol} H), 4.39\left(1 \mathrm{H}, \mathrm{dd},{ }^{3} J_{\mathrm{HH}}=2.5,{ }^{4} J_{\mathrm{HP}}=0.5 \mathrm{~Hz}, \mathrm{CpH}\right), 4.22(5 \mathrm{H}, \mathrm{s}, \mathrm{Cp} H)$, $4.13-4.07(2 \mathrm{H}, \mathrm{m}, \mathrm{CH}+\mathrm{CH}), 3.86-3.78(1 \mathrm{H}, \mathrm{m}, \mathrm{CHH}), 3.57(1 \mathrm{H}$, $\left.\mathrm{dd},{ }^{3} \mathrm{JHH}_{\mathrm{HH}}=2.5,3 J_{\mathrm{HP}}=0.7 \mathrm{~Hz}, \mathrm{CpH}\right), 2.28\left(3 \mathrm{H}, \mathrm{d},{ }^{4} J_{\mathrm{HP}}=1.4 \mathrm{~Hz}, \mathrm{CH}_{3}\right), 1.04$ $\left(1 \mathrm{H}, \mathrm{d},{ }^{3} J_{\mathrm{HH}}=6.5 \mathrm{~Hz}, \mathrm{CH}\right) .{ }^{13} \mathrm{C}\left\{{ }^{1} \mathrm{H}\right\}$ NMR $\left(125 \mathrm{MHz}, \mathrm{CDCl}_{3}\right): 165.4(\mathrm{~d}$, $\left.{ }^{3} J_{\mathrm{CP}}=3.1 \mathrm{~Hz}, C=\mathrm{N}\right), 141.0\left(\mathrm{~d},{ }^{2} J \mathrm{CP}=25.2 \mathrm{~Hz}, o-\mathrm{Tol} C\right), 138.1\left(\mathrm{~d},{ }^{1} J_{\mathrm{CP}}=\right.$ $13.5 \mathrm{~Hz}, o-\mathrm{Tol} C), 137.3\left(\mathrm{~d},{ }^{1} J_{\mathrm{CP}}=12.0 \mathrm{~Hz}, \mathrm{Ph} C\right), 134.9\left(\mathrm{~d},{ }^{2} J_{\mathrm{CP}}=20.9\right.$ $\mathrm{Hz}, \mathrm{PhC}$ ), 131.8 (o-TolC), 129.7 (d, ${ }^{3} \mathrm{CP}_{\mathrm{CP}}=4.6 \mathrm{~Hz}, o-\mathrm{Tol} C$ ), 129.1 $(\mathrm{Ph} C), 128.4\left(\mathrm{~d}, 3 J_{\mathrm{CP}}=7.2 \mathrm{~Hz}, \mathrm{PhC}\right), 128.0(o-\mathrm{Tol} C), 125.5(o-\mathrm{Tol} C)$, $78.7\left(\mathrm{~d},{ }^{2} J_{\mathrm{CP}}=14.2 \mathrm{~Hz}, \mathrm{Cp} C\right), 75.0\left(\mathrm{~d},{ }^{1} J_{\mathrm{CP}}=16.4 \mathrm{~Hz}, \mathrm{Cp} C\right), 74.6\left(\mathrm{~d},{ }^{2}\right)_{\mathrm{CP}}$ $=4.2 \mathrm{~Hz}, \mathrm{Cp} C), 73.8\left(\mathrm{CH}_{2}\right), 71.1\left(\mathrm{~d},{ }^{3} J_{\mathrm{CP}}=0.9 \mathrm{~Hz}, \mathrm{CpC}\right), 61.7(\mathrm{CH})$, 
$21.5\left(\mathrm{CH}_{3}\right), 21.2\left(\mathrm{~d},{ }^{3}{ }_{\mathrm{CP}}=21.2 \mathrm{~Hz}, \mathrm{CH}_{3}\right) .{ }^{31} \mathrm{P}\left\{{ }^{1} \mathrm{H}\right\} \mathrm{NMR}(202 \mathrm{MHz}$, $\mathrm{CDCl}_{3}$ ): -24.02 (Po-TolPh). HRMS (ASAP-TOF) $\mathrm{m} / \mathrm{z}:[\mathrm{M}+\mathrm{H}]^{+}$Calcd for $\mathrm{C}_{27} \mathrm{H}_{25} \mathrm{DFeNOP}+\mathrm{H}^{+}$469.1243; Found 469.1236.

General Procedure for Allylic Alkylation. Ligand $(0.0125 \mathrm{mmol})$ and $[\mathrm{Pd}(\text { allyl }) \mathrm{Cl}]_{2}(0.0019 \mathrm{~g}, 0.005 \mathrm{mmol})$ were added to a flame dried Schlenk tube, dissolved in dichloromethane $(0.85 \mathrm{~mL})$ and allowed to stir for $30 \mathrm{~min}$ at room temperature. In a separate flask, racemic 1,3-diphenylallyl acetate $(0.126 \mathrm{~g}, 0.50 \mathrm{mmol})$ was weighed out and subsequently dissolved in dichloromethane $(0.85$ $\mathrm{mL}$ ). After $30 \mathrm{~min}$, the acetate solution was added to the reaction vessel followed by dimethyl malonate $(0.17 \mathrm{~mL}, 1.5 \mathrm{mmol}), \mathrm{N}, \mathrm{O}$ bis(trimethylsilyl)acetamide $(0.37 \mathrm{~mL}, 1.5 \mathrm{mmol})$ and $\mathrm{KOAc}(0.001$ $\mathrm{g}, 0.01 \mathrm{mmol}$ ) in that order. The reaction was stirred at room temperature and monitored by TLC $\left(\mathrm{SiO}_{2}, 5 \% \mathrm{EtOAc} /\right.$ hexane $)$. After completion or $24 \mathrm{~h}$ (whichever came first), the reaction was quenched with saturated ammonium chloride, separated with diethyl ether, dried with magnesium sulphate and the solvent removed in vacuo. A crude ${ }^{1} \mathrm{H}$ NMR was performed at this point to determine the conversion. Purification by column chromatography $\left(\mathrm{SiO}_{2}, 5 \% \mathrm{EtOAc} /\right.$ hexane$)$ gave the product as a colourless oil. Enantiomeric excess measurements was determined by chiral HPLC analysis using a CHIRALCEL OD-H; Eluent = 98:2 (Hexane:IPA); Flow rate $=0.5 \mathrm{~mL} \mathrm{~min}^{-1}$; Concentration $=0.0015 \mathrm{~g} \mathrm{~mL}^{-1}$, Injection volume $=5 \mu \mathrm{l}$. Major enantiomer RT $=18.8 \mathrm{~min}$, Minor enantiomer $\mathrm{RT}=17.3 \mathrm{~min} .{ }^{1} \mathrm{H}$ NMR $\left(500 \mathrm{MHz}, \mathrm{CDCl}_{3}\right) \delta 7.34-7.27(8 \mathrm{H}, \mathrm{m}, \mathrm{Ph} H)$, $7.26-7.18(2 \mathrm{H}, \mathrm{m}, \mathrm{Ph} H), 6.48\left(1 \mathrm{H}, \mathrm{d},{ }^{3} \mathrm{~J}_{\mathrm{HH}}=15.7 \mathrm{~Hz}, H \mathrm{C}=\mathrm{CH}\right), 6.33$ $\left(1 \mathrm{H}, \mathrm{dd},{ }^{3} J_{\mathrm{HH}}=15.7,{ }^{3} J_{\mathrm{HH}}=8.6 \mathrm{~Hz}, \mathrm{HC}=\mathrm{CH}\right), 4.27\left(1 \mathrm{H}, \mathrm{dd},{ }^{3} \int_{\mathrm{HH}}=10.8\right.$, $\left.{ }^{3} J_{\mathrm{HH}}=8.7 \mathrm{~Hz}, \mathrm{CH}\right), 3.96\left(1 \mathrm{H}, \mathrm{d},{ }^{3} J_{\mathrm{HH}}=10.9 \mathrm{~Hz}, \mathrm{CH}\right), 3.71\left(3 \mathrm{H}, \mathrm{s}, \mathrm{CH}_{3}\right)$, $3.52(3 \mathrm{H}, \mathrm{s}, \mathrm{CH}) \cdot{ }^{13} \mathrm{C}\left\{{ }^{1} \mathrm{H}\right\} \mathrm{NMR}\left(125 \mathrm{MHz}, \mathrm{CDCl}_{3}\right): 168.4(\mathrm{C}=0), 167.9$ $(C=0), 140.3(\mathrm{Ph} C), 137.0(\mathrm{PhC}), 132.0(\mathrm{HC}=\mathrm{CH}), 129.3(\mathrm{HC}=\mathrm{CH})$, $128.9(\mathrm{Ph} C), 128.6(\mathrm{Ph} C), 128.0(\mathrm{Ph} C), 127.7(\mathrm{Ph} C), 127.3(\mathrm{Ph} C)$, $126.5(\mathrm{PhC}), 57.8(\mathrm{CH}), 52.8\left(\mathrm{CH}_{3}\right), 52.6\left(\mathrm{CH}_{3}\right), 49.3(\mathrm{CH})$. Matches previously reported data. ${ }^{32}$

\section{ASSOCIATED CONTENT}

\section{Supporting Information}

The Supporting Information is available free of charge on the ACS Publications website.

Copies of the ${ }^{1} \mathrm{H},{ }_{13} \mathrm{C},{ }_{31} \mathrm{P}$ NMR spectra, HPLC traces and details of the X-ray crystal structure determinations (PDF), together with the associated CIF files.

\section{Accession Codes}

CCDC 1916753, 1916752, and 1916751 contain the supplementary crystallographic data for this paper. These data can be obtained free of charge via www.ccdc.cam.ac.uk/data_request/cif, or by emailing data_request@ccdc.cam.ac.uk, or by contacting The Cambridge Crystallographic Data Centre, 12 Union Road, Cambridge CB2 1EZ, UK; fax: +44 1223336033.

\section{AUTHOR INFORMATION}

\section{Corresponding Author}

*E-mail: chris.richards@uea.ac.uk.

\section{Notes}

The authors declare no competing financial interest.

\section{ACKNOWLEDGMENT}

The EPSRC (EP/N019393/1) (R.A.A.) is thanked for financial support. We also thank the EPSRC National Mass Spectrometry Centre (University of Wales, Swansea).

\section{REFERENCES}

(1) (a) New Frontiers in Asymmetric Catalysis (Eds.: Mikami, K.; Lautens, M.) Wiley, Hoboken. New Jersey 2007. (b) Asymmetric Catalysis on Industrial Scale: Challenges, Approaches and Solutions (Eds: Blaser, H. U.; Federsel, H.-J.) Wiley,Weinheim 2010.

(2) For illustrative recent examples see: (a) Burns, A. R.; González, J. S.; Lam, H. W. Enantioselective Copper(I)-Catalyzed Borylative Aldol Cyclizations of Enone Diones. Angew. Chem. Int. Ed. 2012, 51, 10827-10831. (b) Huang, K.; Li, S.; Chang, M.; Zhang, X. RhodiumCatalyzed Enantioselective Hydrogenation of Oxime Acetates. Org. Lett. 2013, 15, 484-487. (c) Meng, F.; Haeffner, F.; Hoveyda, A. H. Diastereo- and Enantioselective Reactions of Bis(pinacolato)diboron, 1,3-Enynes, and Aldehydes Catalyzed by an Easily Accessible Bisphosphine-Cu Complex. J. Am. Chem. Soc. 2014, 136, 1130411307. (d) Fan, L.; Takizawa, S.; Takeuchi, Y.; Takenaka, K.; Sasai, H. Pd-catalyzed enantioselective intramolecular $\alpha$-arylation of $\alpha$ substituted cyclic ketones: facile synthesis of functionalized chiral spirobicycles. Org. Biomol. Chem. 2015, 13, 4837-4840. (e) Xu, K.; Wang, Y.-H.; Khakyzadeh, V.; Breit, B. Asymmetric Synthesis of allylic amines via hydroamination of allenes with benzophenone imine. Chem. Sci. 2016, 7, 3313-3316. (f) Pujol, A.; Whiting, A. Double Diastereoselective Approach to Chiral syn- and anti-1,3-Diol Analogues through Consecutive Catalytic Asymmetric Borylations. J. Org, Chem. 2017, 82, 7265-7279.

(3) (a) Yoon, T. P.; Jacobsen, E. N. Privileged Chiral Catalysts. Science 2003, 299, 1691-1693. (b) Privileged Chiral Ligands and Catalysts (Ed.: Zhou, Q.-L.) Wiley-VCH, Weinheim 2011.

(4) Miyashita, A.; Yasuda, A.; Takaya, H.; Toriumi, K.; Ito, T.; Souchi, T.; Noyori, R. Synthesis of 2,2'-bis(diphenylphosphino)-1,1'binaphthyl (BINAP), an atropisomeric chiral bis(triaryl)phosphine, and its use in the rhodium(I)-catalyzed asymmetric hydrogenation of $\alpha$-(acylamino)acrylic acids. J. Am. Chem. Soc. 1980, 102, 79327934.

(5) Togni, A.; Breutel, C.; Schnyder, A.; Spindler, F.; Landert, H.; Tijani, A. A Novel Easily Accessible Chiral Ferrocenyldiphosphine for Highly Enantioselective Hydrogenation, Allylic Alkylation, and Hydroboration. J. Am. Chem. Soc. 1994, 116, 4062-4066.

(6) Sturm, T.; Weissensteiner, W.; Spindler, F. A Novel Class of Ferrocenyl-Aryl-Based Diphosphine Ligands for Rh- and Ru-Catalysed Enantioselective Hydrogenation. Adv. Synth. Cat. 2003, 345, 160164.

(7) (a) Whitesell, J. K. $C_{2}$ Symmetry and Asymmetric Induction. Chem. Rev. 1989, 89, 1581-1590. (b) Pfaltz, A.; Drury III, W. J. Design of chiral ligands for asymmetric catalysis: From $\mathrm{C}_{2}$-symmetric $\mathrm{P}, \mathrm{P}-$ and $\mathrm{N}, \mathrm{N}$-ligands to sterically and electronically nonsymmetrical P,N-ligands. PNAS 2004, 101, 5723-5726.

(8) For example, the diastereoisomers of Josiphos and Walphos used are a consequence of the highly diastereoselective lithiation of Ugi's amine, a precursor used in the synthesis of both ligands. See: Marquarding, D.; Klusacek, H.; Gokel, G.; Hoffmann, P.; Ugi, I. Stereoselective syntheses. VI. Correlation of central and planar chirality in ferrocene derivatives. J. Am. Chem. Soc. 1970, 92, 53895393.

(9) For example see: (a) Li, W.; Zhang, X. Synthesis of 3,4-O-Isopropylidene- $(3 S, 4 S)$-dihydroxy- $(2 R, 5 R)$-bis(diphe-

nylphosphino)hexane and Its Application in Rh-Catalyzed Highly Enantioselective Hydrogenation of Enamides. J. Org. Chem. 2000, 65, 5871-5874. (b) Yan, Y.-Y.; RajanBabu, T. V. Ligand Substituent Effects on Asymmetric Induction. Effect of Structural Variations of the DIOP Ligand on the Rh-Catalyzed Asymmetric Hydrogenation of Enamides. Org. Lett. 2000, 2, 4137-4140. (c) Qiu, L.; Oi, J.; Pai, C.C.; Chan, S.; Zhou, Z.; Choi, M. C. K.; Chan, A. S. C. Synthesis of Novel Diastereomeric Diphosphine Ligands and Their Applications in Asymmetric Hydrogenation Reactions. Org. Lett. 2002, 4, 45994602. (d) Li, M.; Yuan. K.; Li, Y.-Y.; Cao, B.-X.; Sun, J.; Hou, X.-L. On the role of planar chirality in asymmetric catalysis: Improvement of enantioselectivity in the addition of diethylzinc to aldehydes with planar chiral $1,1^{\prime}$ - $N, O$-ferrocenyl ligands. Tetrahedron: Asymmetry 2003, 14, 3347-3352. (e) Hu, X.-P.; Zheng, Z. Unsymmetrical Hybrid Ferrocene-Based Phosphine-Phosphoramidites: A New 
Class of Practical Ligands for Rh-Catalyzed Asymmetric Hydrogenation. Org. Lett. 2004, 6, 3585-3588. (f) Song, X.-G.; Zhu, S.-F.; Xie, X-L.; Zhou, Q.-L. Enantioselective Copper-Catalyzed Intramolecular Phenolic O-H Bond Insertion: Synthesis of Chiral 2-Carboxy Dihydrobenzofurans, Dihydrobenzopyrans, and Tetrahydrobenzooxepines. Angew. Chem. Int. Ed. 2013, 52, 2555-2558.

(10) Three of the four possible diastereoisomers of a ferrocenebased ligand containing three elements of chirality have been synthesised and applied to ruthenium-catalysed hydrogenation and transfer hydrogenation. See: a) Schuecker, R.; Zirakzadeh, A.; Mereiter, K.; Spindler, F.; Weissensteiner, W. Synthesis, Coordination Behavior, and Structural Features of Chiral Amino-, Pyrazolyl, and Phosphino-Substituted Ferrocenyloxazolines and Their Application in Asymmetric Hydrogenations. Organometallics 2011, 30, 4711-4719. b) Zirakzadeh, A.; Schuecker, R.; Gorgas, N.; Mereiter, K.; Spindler, F.; Weissensteiner, W. Ruthenium Complexes of Phosphino-Substituted Ferrocenyloxazolines in the Asymmetric Hydrogenation and Transfer Hydrogenation of Ketones: A Comparison. Organometallics 2012, 31, 4241-4250.

(11) Sammakia, T.; Latham, H. A. Ligand effects on the stereochemistry of the metalation of chiral ferrocenyloxazolines. J. Org. Chem. 1995, 60, 6002-6003.

(12) (a) Richards, C. J.; Damalidis, T.; Hibbs, D. E.; Hursthouse, M. B. Synthesis of 2-[2-(Diphenylphosphino)ferrocenyl]oxazoline Ligands. Synlett 1995, 74-76. (b) Nishibayashi, Y.; Uemura, S. Asymmetric Synthesis and Highly Diastereoselective ortho-Lithiation of Oxazolinylferrocenes. Synlett 1995, 79-81. (c) Richards, C. J.; Mulvaney, A. W. Synthesis of Phosphin oferrocenyloxazolines. New Ligands for Asymmetric Catalysis. Tetrahedron: Asymmetry 1996, 7, 14191430.

(13) Examples for each metal include: (a) Pd: You, S.-I.; Hou, X.-L.; Dai, L.-X.; Yu, Y.-H.; Xia, W. Role of Planar Chirality of $S, N$ and $P, N$ Ferrocene Ligands in Palladium-Catalyzed Allylic Substitutions. J. Org. Chem. 2002, 67, 4684-4695. (b) Ru: Onodera, G.; Nishibayashi, Y.; Uemura, S. Ir- and Ru-Catalyzed Sequential Reactions: Asymmetric $\alpha$-Alkylative Reduction of Ketones with Alcohols. Angew. Chem. Int. Ed. 2006, 45, 3819-3822. (c) Ir: Lu, S.-M.; Han, X.-W.; Zhou, Y.-G. Asymmetric Hydrogenation of Quinolines Catalyzed by Iridium with Chiral Ferrocenyloxazoline Derived N,P Ligands. Adv. Synth. Cat. 2004, 346, 909-912. (d) Ag: Liu, K.; Xiong, Y.; Wang, Z.F.; Tao, H.-Y.; Wang, C.-J. Ligand-controlled stereodivergent 1,3-dipolar cycloaddition of azomethine ylides with 3-methyl-4-nitro-5styrylisoxazoles. Chem. Commun. 2016, 52, 9458-9461. (e) Cu: Wei, L.; Zhu, Q.; Xu, S.-M.; Chang, X.; Wang, C.-J. Stereodivergent Synthesis of $\alpha, \alpha$-Disubstituted $\alpha$-Amino Acids via Synergistic $\mathrm{Cu} / \mathrm{Ir}$ Catalysis. J. Am. Chem. Soc. 2018, 140, 1508-1513. (f) Ni: Hernandez, L. W.; Klöckner, U.; Pospech, J.; Hauss, L.; Sarlah, D. Nickel-Catalyzed Dearomative trans-1,2-Carboamination. J. Am. Chem. Soc. 2018, 140, 4503-4507.

(14) In this Letter compounds that differ only by the presence or absence of deuterium have the same number. In all cases position 1 of the substituted cyclopentadienyl ring is attached to the oxazoline substituent. Planar chiral configurations are assigned by the Schlögl convention. See: (a) Schlögl, K.; Fried, M. Über Optisch Aktive Kohlenwasserstoffe der Ferrocenreihe. Tetrahedron Lett. 1963, 4, 1473. (b) Schlögl, K.; Fried, M.; Falk, H. Die relative Konfiguration von optisch aktiven, $\alpha$-disubstituierten Ferrocenderivaten. Monatsh. Chem. 1964, 95, 576-597.

(15) Arthurs, R. A.; Richards, C. J. Deuterium as a Stereochemically Invisible Blocking Group for Chiral Ligand Synthesis. Org. Lett. 2017, 19, 702-705.

(16) (a) Pietrusiewicz, K. M.; Zablocka, M. Preparation of Scalemic P-Chiral Phosphines and Their Derivatives. Chem. Rev. 1994, 94, 1375-1411. (b) Grabulosa, A.; Granell, J.; Muller, G. Preparation of optically pure $P$-stereogenic trivalent phosphorus compounds. Coord. Chem. Rev. 2007, 251, 25-90. (c) Kolodiazhnyi, O. I. Recent developments in the asymmetric synthesis of $P$-chiral phosphorus compounds. Tetrahedron: Asymmetry 2012, 23, 1-46. (d) Dutartre, M.; Bayardon, J.; Jugé, S. Applications and stereoselective syntheses of P-chirogenic phosphorus compounds. Chem. Soc. Rev. 2016, 45, 5771-5794.

(17) (a) Segi, M.; Nakamura, Y.; Nakajima, T.; Suga, S. Preparation of Optically Active Phosphine Oxides by Regioselective Cleavage of Cyclic Phenylphosphonite with Alkyl Halides. Chem. Lett. 1983, 913-916. (b) Jugé, S.; Stephan, M.; Laffitte, J. A.; Genet, J. P. Efficient Asymmetric Synthesis of Optically Pure Tertiary Mono and Diphosphine Ligands. Tetrahedron Lett. 1990, 31, 6357-6360. (c) Corey, E. J.; Chen, Z.; Tanoury, G. J. A New and Highly Enantioselective Synthetic Route to P-Chiral Phosphines and Diphosphines. J. Am. Chem. Soc. 1993, 115, 11000-11001. (d) Kolodiazhnyi, O. I.; Grishkun, E. V. Simple Route to Chiral Organophosphorus Compounds. Tetrahedron: Asymmetry 1996, 7, 967-970. (e) Rippert, A. J.; Linden, A.; Hansen, H. J. Formation of Diastereomerically Pure Oxazaphospholes and Their Reaction to Chiral Phosphane-Borane Adducts. Helv. Chim. Acta 2000, 83, 311-321.

(18) (a) Chen, W.; Mbafor, W.; Roberts, S. M.; Whittall, J. A Very Simple, Highly Stereoselective and Modular Synthesis of FerroceneBased P-Chiral Phosphine Ligands. J. Am. Chem. Soc. 2006, 18, 3922-3923. (b) See also: Chen, W.; Roberts, S. M.; Whittall, J.; Steiner, A. An efficient and highly stereoselective synthesis of new $P$ chiral 1,5-diphosphanylferrocene ligands and their use in enantioselective hydrogenation. Chem. Commun. 2006, 2916-2918. (19) CCDC 1916753, 1916752, and 1916751 (L3a, L4a, L6b) contain the supplementary crystallographic data for this paper. These data can be obtained free of charge from The Cambridge Crystallographic Data Centre.

(20) Hoppe, D.; Paetow, M.; Hintze, F. Stereodivergent Enantioselective Synthesis by Exploiting Unusually Large Kinetic H/D Isotope Effects on Deprotonation. Angew. Chem., Int. Ed. Engl. 1993, 32, 394-396.

(21) Schwenk, R.; Togni, A. P-Trifluoromethyl ligands derived from Josiphos in the Ir-catalysed hydrogenation of 3,4-dihydroisoquinoline hydrochlorides. Dalton Trans. 2015, 44, 19566-19575.

(22) The electron-rich nature of the ferrocenyl substituent increases the p-character of the lone pair orbital reducing the energy required for rehybridization to the trigonal planar transition state needed for epimerisation. This can be countered by use of an electron-withdrawing substituent on phosphorus. See reference 21.

(23) Kropp, P. J.; Breton, G. W.; Craig, S. L.; Crawford, S. D.; Durland, Jr. W. F.; Jones, III, J. E.; Raleigh, J. S. Surface-Mediated Reactions. 6. Effects of Silica Gel and Alumina on Acid-Catalyzed Reactions. J. Org. Chem. 1995, 60, 4146-4152.

(24) Epimerisation was not a problem during chromatography provided the time taken was less than $c a$. 20 min (excepting relatively polar ligand $\mathbf{L 5 b}$ which was not separated readily). Use of alumina resulted in no separation.

(25) Carey, J. V.; Barker, M. D.; Brown, J. M.; Russell, M. J. H. Preparation of enantiomerically pure phosphine oxides by nucleophilic displacement chemistry using oxazaphospholidines. J. Chem. Soc., Perkin 1 1993, 831-839.

(26) Burford, N.; Losier, P.; Phillips, A. D.; Ragogna, P. J.; Cameron, T. S. Nitrogen Ligands on Phosphorus(III) Lewis Acceptors: A Versatile New Synthetic Approach to Unusual N-P Structural Arrangements. Inorg. Chem. 2003, 42, 1087-1091.

(27) Correction values determined from the comparison of the ${ }^{31} \mathrm{P}$ $\mathrm{NMR}$ value for $\mathrm{PPh}_{3}(-6.0 \mathrm{ppm})$ with the values for $\mathrm{FCPPh}_{2}(-15.4)$ and $o-\mathrm{TolPPh}_{2}(-12.4)$. On the same basis, starting with $\mathrm{Ph}_{2} \mathrm{PCl}(81)$, the estimated value for $\left(S, S_{\mathrm{p}}\right)-3$ is $c a .65$, and thus also compatible with the observed intermediate.

(28) Related phosphinooxazoline ligands containing a phosphorus-based stereogenic centre have been synthesised with modest diastereocontrol. Distinct matched/mismatched outcomes were observed for the palladium catalysed allylic alkylation of cyclic substrates. See: (a) Peer, M.; de Jong, J. C.; Kiefer, M.; Langer, T.; Rieck, H.; Schell, H.; Sennhenn, P.; Sprinz, J.; Steinhagen, H.; Wiese, B.; Helmchen, G. Preparation of chiral phosphorus, sulfur and selenium containing 2-aryloxazoline. Tetrahedron 1996, 52, 75477583. (b) Kudis, S.; Helmchen, G. Enantioselective Allylic 
Substitution of Cyclic Substrates by Catalysis with Palladium Complexes of P,N-Chelate Ligands with a Cymantrene Unit. Angew. Chem. Int. Ed. 1998, 37, 3047-3050.

(29) A reasonable assumption for this reaction as enantioselectivity arises in the trans to phosphorus addition of the nucleophile to an $\eta^{3}$-trans,trans-1,3-diphenylallyl palladium intermediate, for which the two possible endo/exo isomers result in $(S)$ - and $(R)-6$ respectively. See: Helmchen, G.; Pfaltz, A. Phosphinooxazoline-A New Class of Versatile, Modular P,N-Ligands for Asymmetric Catalysis. Acc. Chem. Res. 2000, 33, 336-345.

(30) Richards, C. J.; Arthurs, R. A. Catalyst Optimisation for Asymmetric Synthesis by Ligand Chirality Element Addition: A
Perspective on Stereochemical Cooperativity. Chem. Eur. J. 2017, 23, 11460-11478.

(31) Dailler, D.; Rocaboy, R.; Baudoin, O. Synthesis of $\beta$-Lactams by Palladium(0)-Catalyzed C( $\left.\mathrm{sp}^{3}\right)-\mathrm{H}$ Carbamoylation. Angew. Chem. Int. Ed. 2017, 56, 7218-7222.

(32) (a) Tanaka, Y.; Mino, T.; Akita, K.; Sakamoto, M.; Fujita, T. Development of Chiral (S)-Prolinol-Derived Ligands for PalladiumCatalyzed Asymmetric Allylic Alkylation: Effect of a Siloxymethyl Group on the Pyrrolidine Backbone. J. Org. Chem. 2004, 69, 66796687. (b) Liu, D.; Xie, F.; Zhang, W. Novel C2-Symmetric Planar Chiral Diphosphine Ligands and Their Application in Pd-Catalyzed Asymmetric Allylic Substitutions. J. Org. Chem. 2007, 72, 69926997. 